\title{
Long-term variations of surface chlorophyll $a$ and primary production in the open Black Sea
}

\author{
Oleg A. Yunev ${ }^{1, *}$, Vladimir I. Vedernikov², Ozden Basturk ${ }^{3}$, Aysen Yilmaz ${ }^{3}$, \\ Ahmet E. Kideys ${ }^{3}$, Snejana Moncheva ${ }^{4}$, Sergey K. Konovalov ${ }^{5}$ \\ ${ }^{1}$ Institute of Biology of the Southern Seas, National Academy of the Sciences of Ukraine, Nakhimov Av. 2, \\ Sevastopol 335011, Ukraine \\ ${ }^{2}$ P. P. Shirshov Institute of Oceanology, Russian Academy of Sciences, Moscow, Russia \\ ${ }^{3}$ Middle East Technical University, Institute of Marine Sciences, Erdemli, Icel, Turkey \\ ${ }^{4}$ Institute of Oceanology, Bulgarian Academy of Sciences, Varna, Bulgaria \\ ${ }^{5}$ Marine Hydrophysical Institute, National Academy of the Sciences of Ukraine, Sevastopol, Ukraine
}

\begin{abstract}
Extensive data sets on surface chlorophyll a (chl a), depth-integrated primary production (DIPP) and phosphate $\left(\mathrm{PO}_{4}, \mu \mathrm{M}\right)$ averaged for the upper $25 \mathrm{~m}$ layer in 1964, 1973, 1978 and for a period (1980 to 1996) of regular measurements have been used to evaluate long-term changes in the upper portion of the euphotic layer of the entire open $(>1000 \mathrm{~m})$ Black Sea. After preliminary analysis of seasonal dynamics, special attention was given to data obtained during those periods of the year with relatively stable values, revealing interannual and long-term fluctuations and trends. Of 2 phytoplankton characteristics (chl $a$ and DIPP), long-term trends were obtained only for chl a since only these data covered the entire open sea and all periods investiged. A positive correlation was found between DIPP (using 2 different ${ }^{14} \mathrm{C}$ methods: actual in situ and simulated in situ) and the more numerous chl a data for different monthly intervals, with significant correlation coefficients $(\mathrm{r}=0.51$ to 0.82$)$. This means that the observed patterns in long-term variability for chl a may be valid also for DIPP. The results show that interannual fluctuations in chl $a$ are more pronounced during the warm months, from approximately May to September. Chl a levels within this interval were moderate, with a mean of $0.15 \pm$ $0.04 \mathrm{mg} \mathrm{m}^{-3}$ during the first 'quiet' period (1964 to 1986), but increased steadily at a rate of $0.06 \mathrm{mg} \mathrm{m}^{-3}$ $\mathrm{yr}^{-1}$ during 1988 to 1991 and sharply in 1992 (mainly due to high July values) to $0.99 \pm 0.7 \mathrm{mg} \mathrm{m}^{-3}$. In contrast, negative trends were characteristic of the third period (1993 to 1996): an abrupt decrease in chl $a$ to $0.26 \pm 0.08 \mathrm{mg} \mathrm{m}^{-3}$ in 1993 and a negative trend $\left(-0.02 \mathrm{mg} \mathrm{m}^{-3} \mathrm{yr}^{-1}\right)$ during 1993 to 1996. Low concentrations of $\mathrm{PO}_{4}(0.015$ to $0.138 \mu \mathrm{M})$ in the upper $25 \mathrm{~m}$ layer throughout the year and the absence of statistically reliable interannual trends in distribution suggest that this nutrient was limiting the level of primary production during the second period. This means that phosphate concentration in the upper 25 m layer cannot be considered a reliable indicator of the presence or absence of anthropogenic eutrophication in the open Black Sea. This long-term variability in phytoplankton characteristics agrees well with the data on interannual changes in other ecological variables of the open Black Sea characterized by a collapse of the Black Sea ecosystem during the second period and its recovery after 1992. Comparison of changes in the open and shelf areas of the Black Sea between these 3 periods, and similar changes in the plankton community and in pelagic fish stocks in the second half of the 1980s to the beginning of the 1990s in other regions of the northern hemisphere, connected with changes in the climatic regime during this period, have led us to conclude that global climatic processes have played an important role in changing the phytoplankton characteristics of the open Black Sea and affecting the whole pelagic ecosystem, especially over the last 2 decades.
\end{abstract}

KEY WORDS: Surface chlorophyll · Primary production · Phosphate · Open Black Sea - Seasonal, interannual and long-term variability

Resale or republication not permitted without written consent of the publisher

\section{INTRODUCTION}

The Black Sea basin, with its limited size and almost complete enclosure, displays unique circulation char- acteristics and permanent stratification that divides the basin into upper aerobic (comprising only $13 \%$ of the total volume of the basin) and bottom anaerobic zones. The Black Sea receives significant anthropogenic 
inputs from many rivers. All these factors make it ideal for studying natural biological cycles and human impact on its ecosystem (Mee 1992, Unluata et al. 1993, Ozsoy \& Unluata 1997).

Since the late 1960s, increased eutrophication has been reported with negative effects on the coastal ecosystem of the Black Sea (Tolmazin 1985, Bologa 1986, Chirea \& Gomoiu 1986, Mee 1992, Tugrul et al. 1992, Saydam et al. 1993, Zaitsev 1993, Cociasu et al. 1996, Zaitsev \& Aleksandrov 1997, Petranu et al. 1999). The area most affected is the northwestern Black Sea, especially the Romanian coastal shelf zone, which receives water from the rivers Dnieper, Dniester and the Danube. Ecological changes in open-sea regions of the Black Sea have received less attention than those of coastal regions. These open-sea areas constitute a partially isolated ecosystem in which water masses are separated from polluted coastal areas by a meandering 'Rim Current' frontal zone (Vinogradov et al. 1992, Oguz et al. 1993).

Structural and functional characteristics of the phytoplankton are closely related to the intensity of eutrophication (Raymont 1980), and can be used as indices for determining the state of the phytoplankton community in the Black Sea (Vinogradov et al. 1999). Therefore, tracing temporal variations in chlorophyll a (chl a), an acceptable index of phytoplankton biomass, as well as in primary production, is necessary in order to reliably identify changes induced by human activity or by natural fluctuations.

Moreover, the determination of seasonal variations in chlorophyll and primary production is also vitally important for developing ecosystem models. The application of such models to the Black Sea ecosystem requires seasonal observations that are as complete as possible, since significant fluctuations in abiotic factors at temperate latitudes are reflected by variability in phytoplankton characteristics (Finenko 1979, Raymont 1980, Chebotarev et al. 1983, Vedernikov at al. 1983, Vedernikov \& Demidov 1993).

The first measurements of chl $a$ in the Black Sea were made in 1961 (Finenko 1965). Since then, many studies related to, or directly examining monthly, seasonal and interannual changes in chl a and primary production levels have been carried out in different regions of the open Black Sea (Finenko 1967, Vedernikov et al. 1980, 1983, Yunev et al. 1987, Stelmakh et al. 1988, Vedernikov 1989, 1991, Yunev 1989, Krupatkina et al. 1990, 1991, Berseneva 1993, Finenko \& Krupatkina 1993, Vedernikov \& Demidov 1993, 1997, Yilmaz et al. 1998a, b, Bologa et al. 1999, Demidov 1999). Despite these numerous measurements, there are no data on long-term variations in chlorophyll and primary production in the deeper regions of the Black Sea. Therefore (for example) any anthropogenic im- pact on the pelagic ecosystem of the basin would be difficult to discern.

The main aim of the present work was to analyse the seasonal and long-term variability in surface chl a (mg $\mathrm{m}^{-3}$ ) and depth-integrated primary production (DIPP, $\mathrm{mg} \mathrm{C} \mathrm{m}^{-2} \mathrm{~d}^{-1}$ ) in the open Black Sea (>1000 m) primarily over the period of 1980 to 1996, for which regular measurements of these parameters are available.

The concentrations of phosphate averaged for the upper $25 \mathrm{~m}$ layer $\left(\mathrm{PO}_{4}, \mu \mathrm{M}\right)$ were used as an additional index for evaluating anthropogenic influences on the pelagic ecosystem of the Black Sea. Nitrate data are not included, since reliable data for nitrate levels were available only after the mid-1980s, and although the ammonia data for the euphotic layer go back earlier, these older data are not reliable. Therefore, only the phosphate data could be used to study long-term changes in important ecological parameters within the upper portion of the euphotic layer of the open Black Sea.

A statistical methodology, highlighting the interannual and long-term fluctuations and trends of data for certain monthly periods with relatively stable values of the variables investigated was applied for the first time to the Black Sea in this study.

\section{MATERIALS AND METHODS}

The analysis of temporal variability of chl $a$, DIPP and $\mathrm{PO}_{4}$ used data sets comprising numerous determinations of these variables $(\sim 1000,230$ and 1250 measurements of chl $a$, DIPP and $\mathrm{PO}_{4}$, respectively) in deep areas (>1000 m) of the open Black Sea in 1964, 1973, 1978 and for the 1980 to 1996 period of regular measurements (Table 1). All the data in the present study were derived from 3 sources: the database prepared within the framework of the NATO TU Black Sea Project (TU-BS DB); the database of the Department of Ecological Physiology of Phytoplankton at the Institute of Biology of the Southern Seas (Sevastopol, Ukraine); and the data from the Institute of Oceanology, Bulgarian Academy of Sciences (Varna).

For the analysis of temporal variations in $\mathrm{PO}_{4}$ levels, depth integration was carried out using phosphate concentrations measured mainly at 3 to 4 different depths in the upper $25 \mathrm{~m}$ layer of the euphotic zone. The average phosphate concentration was close to surface concentrations because of the upper $\sim 25 \mathrm{~m}$ thick mixed layer that was quasi-homogeneous (as regards both temperature and nutrient levels) in the open Black Sea throughout the year (Cokacar \& Ozsoy 1998). The $\mathrm{PO}_{4}$-analysis techniques and criteria for the joint use of data by the Black Sea riparian countries are given in the reports of the TU-BS DB chemical expert 


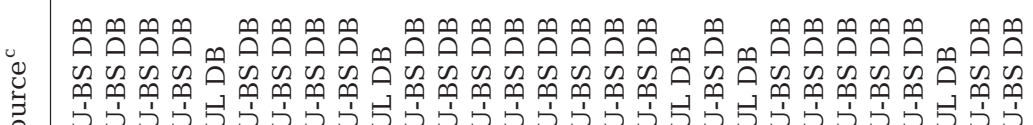

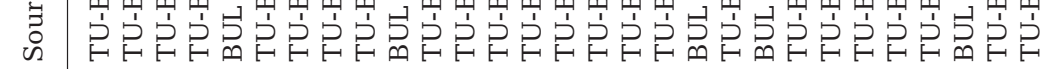

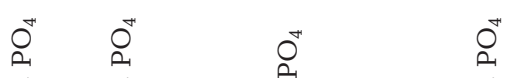

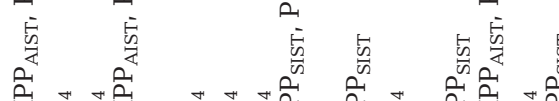

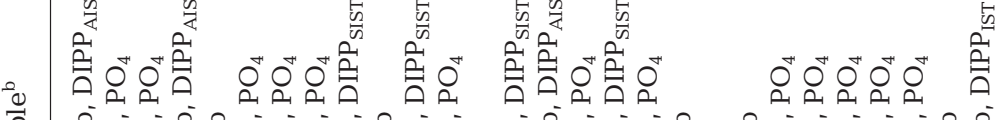

की

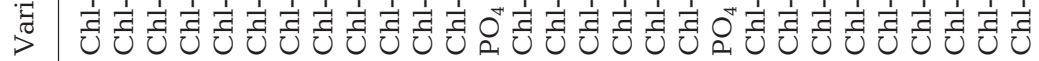

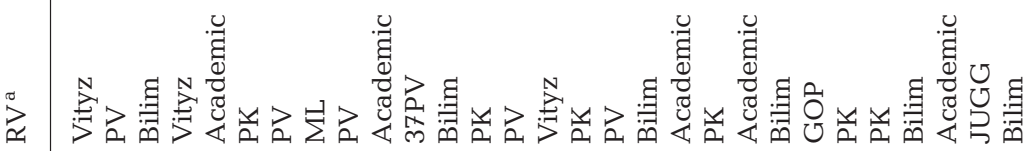

我

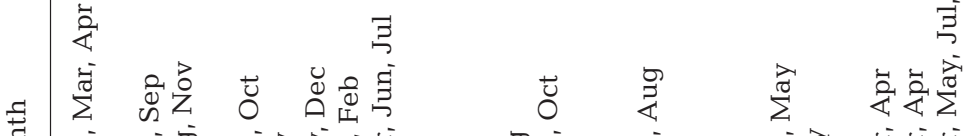

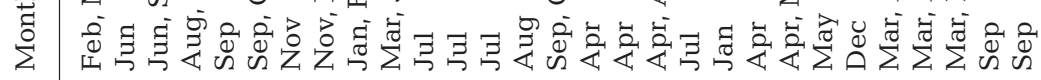

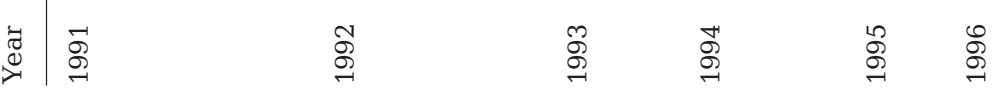

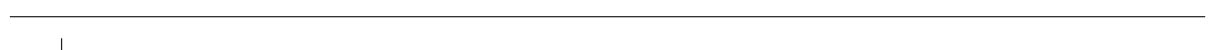

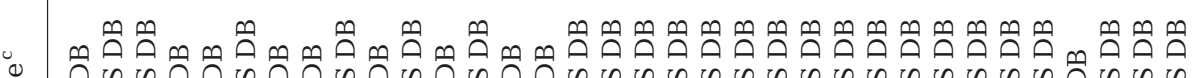

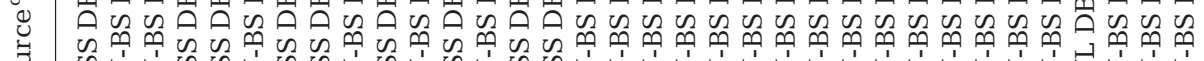

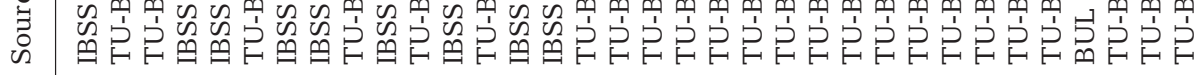

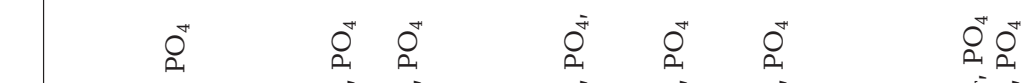

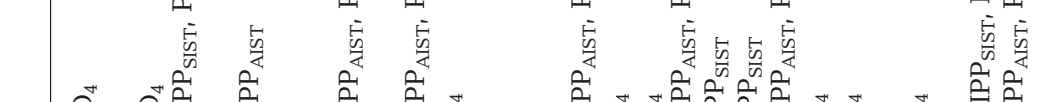

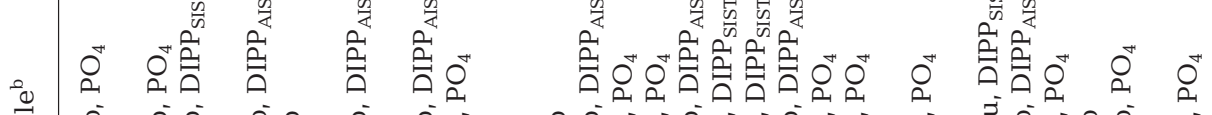

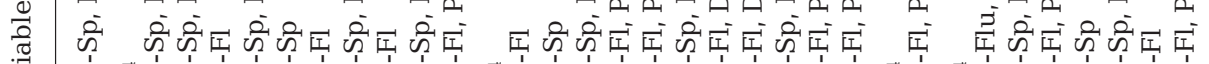

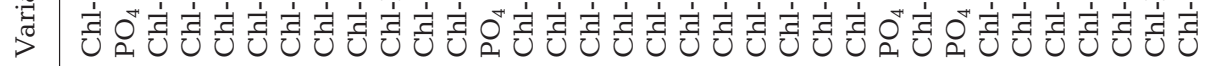

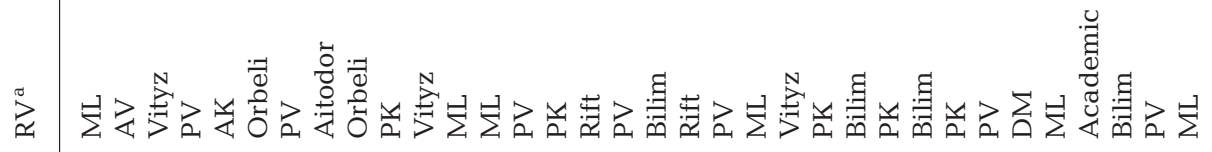

$$
\text { 焉离 }
$$

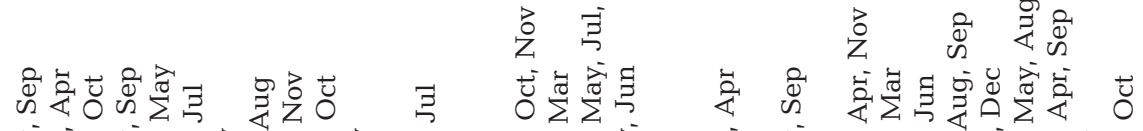

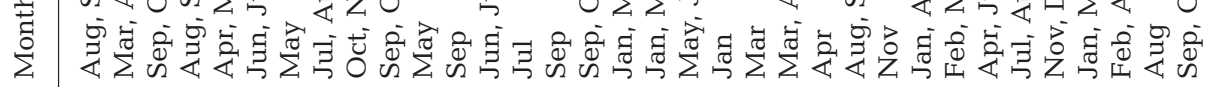

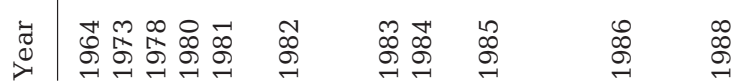

$\underset{\infty}{\infty}$

$\stackrel{8}{\stackrel{\circ}{\rightarrow}}$

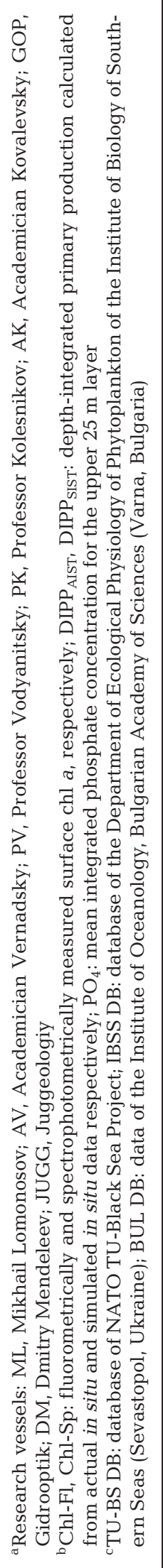


group (Ivanov et al. 1998). Details of errors detected during the quality evaluation of the chl $a$ and DIPP data delivered to the TU-BS DB are given in the report of the bio-optical expert group (Ivanov et al. 1998).

Approximately $70 \%$ of all chl a data used in this investigation were obtained by the standard fluorometric method (JGOFS 1994) and $30 \%$ by the standard spectrophotometric method (Jeffrey \& Humphrey 1975, SCOR-UNESCO 1966). The most detailed statistical comparisons of 5 different techniques for chlorophyll measurement, including high-performance liquid chromatography (HPLC), were made by 2 expert working groups (Neveux et al. 1990, Mantoura et al. 1997). Both groups used various types of mono-alga cultures, seawater and sediment samples for pigment measurements. In almost all cases, the spectrophotometric, fluorometric and HPLC methods showed good agreement for chl a measurements, except for the spectrophotometric results of Jeffrey \& Humphrey (1975), which indicated high phaeopigment a concentrations in the samples (usually $>50 \%$ of the total chl $a$ plus phaeopigment $a$ ), and the fluorometric results of JGOFS (1994), which indicated a high chl $b$ concentration.

Low phaeopigment a content (usually $<30 \%$ of total chl a plus phaeopigment $a$ ) measured both by fluorometric and spectrophotometric methods (Yunev 1989, Krupatkina et al. 1990, Berseneva 1993, Vedernikov \& Demidov 1993), and small contributions from chl $b$ containing phytoplankton (Georgieva 1993) throughout the year are known to be characteristic of the surface layer of the open Black Sea. It should be noted that the chl $a$ and primary production measurements in Table 1 involved a filtration technique using glassfiber-type filters (usually Whatman GF/F) or various membrane filters of 0.3 to $0.6 \mu \mathrm{m}$ pore size during different cruises.

The above chl a data obtained by different standard methods were combined to form a single data set for analysis of temporal variability. However, neither of the expert reports (Neveux et al. 1990, Mantoura et al. 1997) considered problems arising through differences in water filtration, pigment extraction (solvents, grinding, extraction time) or filter-storage techniques before pigment extraction. It is also necessary to note that the Ukrainian cruises used a home-made fluorometer (Yunev 1989) which differed from the Turner fluorometer used by the expert working groups.

To clarify these problems, an experiment was conducted whereby the chl a content of parallel samples, taken from different depths of the euphotic zone in the shelf and deep-water areas of the Black Sea, were measured by 2 standard methods: spectrophotometry (Jeffrey \& Humphrey 1975) and fluorometry (JGOFS 1994), during the March-April 1999 cruise of RV
'Vodyanitsky'. All stages of these 2 standard techniques, prior to chl a measurement, were followed for the respective methods.

Primary production in the water column was measured by 2 modified versions of the radiocarbon method introduced by Steeman Nielsen (1952). With the actual in situ technique (AIST), samples from 6 to 12 depths are resuspended in the water column at corresponding depths after radioactive isotope addition and exposed to natural solar radiation in the sea for $6 \mathrm{~h}$ (Vedernikov et al. 1996). In contrast, in primary production measurements using the simulated in situ technique (SIST) (Krupatkina et al. 1991, Finenko \& Krupatkina 1993), water samples collected from 8 depths in the euphotic zone corresponding to 100,63, $34,12,5,2,1$ and $0.5 \%$ of surface solar irradiance are exposed on deck directly to sunlight for half a day in an appropriate incubator flushed with seawater pumped from the sea surface. Nylon screens are used to reduce the light intensity to that of the light level at the respective sampling depth. Light intensity was continuously measured with a U-116 luxmeter, and the incubation temperature was approximately the same as that at the sea surface during the exposure period.

DIPP was calculated from the depth integration of primary production values obtained by SIST at 139 stations $\left(\right.$ DIPP $\left._{\text {SIST }}\right)$ and by AIST at 96 stations (DIPP AIST $)$ from different depths of the euphotic zone. The results of various ${ }^{14} \mathrm{C}$ methods for measuring primary production in 12 laboratories representing 9 countries showed very significant differences even when using the 'standard method' (Richardson 1991). Therefore, we analysed the temporal variability in DIPP $_{\text {SIST }}$ and DIPP $_{\text {AIST }}$ data separately.

As a first approach, the temporal variability of the investigated parameters was examined for different sub-regions of the open Black Sea (Fig. 1A). These regions were designated on the basis of basin bathymetry, the scheme of the surface currents, the surface chl a maps constructed by using the Nimbus-7 CZCS data for 1978 to 1986, and actual observations of anthropogenic impacts on the shelf areas (Mee 1992, Oguz et al. 1993, Unluata et al. 1993, Zaitsev 1993, Sur et al. 1994, 1996, Cociasu et al. 1996, Ozsoy \& Unluata 1997, Cokacar \& Ozsoy 1998, Kopelevich et al. 2002).

The bottom topography of the Black Sea consists of an abyssal plain separated from the margins by steep continental slopes, except for the gentler slopes near the Danube and Crimean coast (Fig. 1). The region covering depths of $>1000 \mathrm{~m}$ comprises about $75 \%$ of the total surface area. The wider northwestern continental shelf, bounded by a depth of about $100 \mathrm{~m}$ at the shelf break, extends along the western and southwestern coasts of the Black Sea. Along all eastern and southeastern parts of the sea, the shelf break is located 

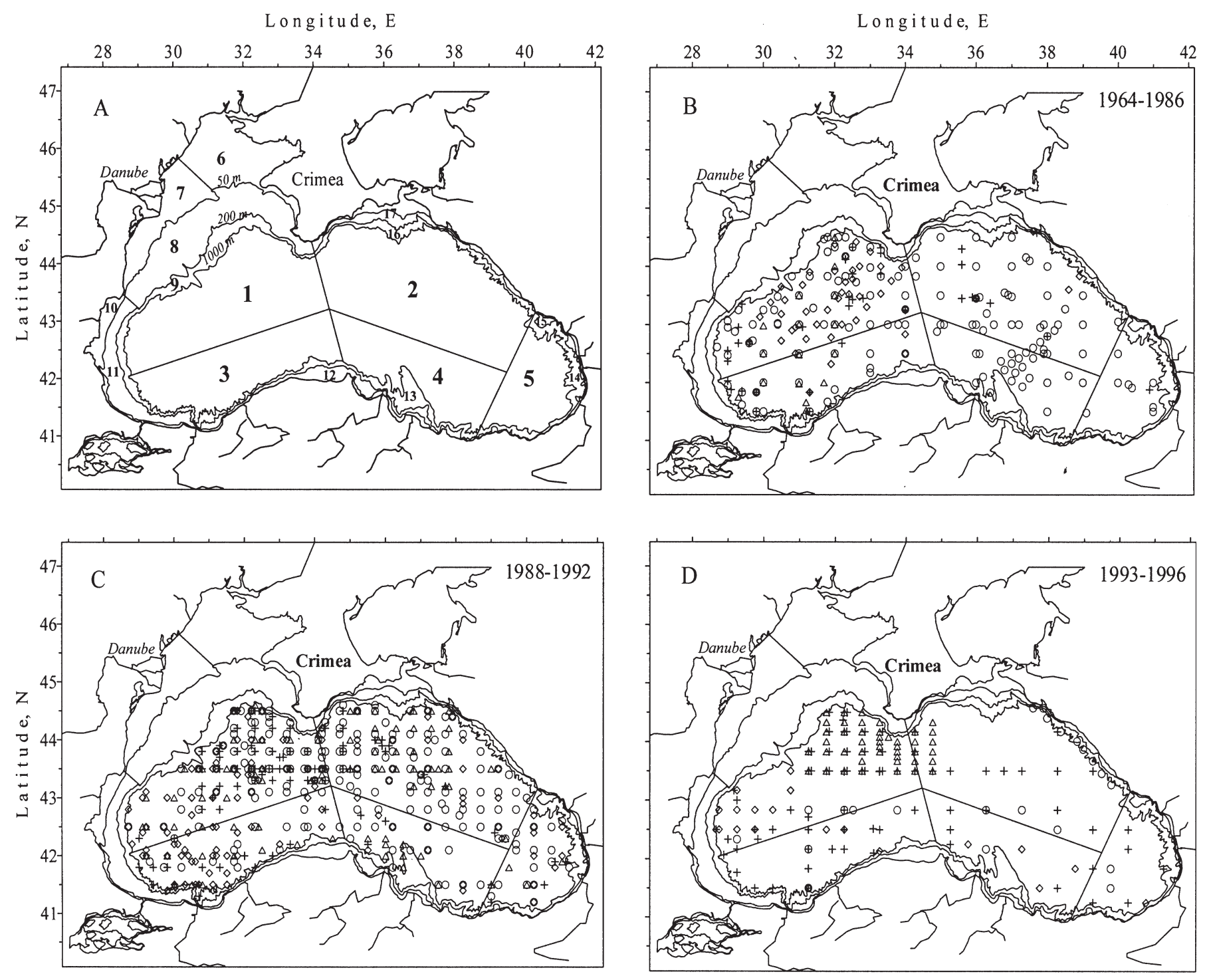

Fig. 1. Sub-regions of the Black Sea (A) and location of stations where chl a measurements in various open (>1000 m) regions were made during 3 interannual periods (B-D). (+) March to May; $(\Delta)$ December to February; $(\diamond)$ June to August; $(\mathbf{O})$ September to November

approximately $20 \mathrm{~km}$ offshore, and the slope drops to $2000 \mathrm{~m}$ depth at a distance of $20 \mathrm{~km}$.

CZCS (coastal zone color scanner) data show detectable differences in pigment concentrations between the western continental shelf/Rim Current zone and the interior regions (USGOFSO 1989, Sur et al. 1994, 1996). The satellite data also show a gradual decrease along the periphery from the northwest shelf zone toward the south. After 'recalibration' of satellite data with in situ Black Sea data (Kopelevich et al. 2002), the mean summer chl a level in the northwestern and western interior shelf was seen to be 13 to 14 times higher than in the open parts, and about 8 times higher than in the eastern shelf-slope.
As in all the world oceans, physical processes such as circulation dynamics and mixing of the ambient waters are important factors influencing the variability in chemical and biological processes that control the productivity of the Black Sea (Sur et al. 1994, 1996, Cokacar \& Ozsoy 1998). The general water circulation in the Black Sea has been described as a basin-scale, cyclonically meandering, boundary current ('Rim Current': Oguz et al. 1993). The interior of the Rim Current frontal zone is formed by 2 cyclonic cells occupying the western and eastern halves of the basin, which are in contact with each other by 2 anticyclonic mesoscale eddies between Crimea and Anatolia (Oguz et al. 1993). In addition to these features, a series of anti- 
cyclonic eddies are confined inshore of the Rim Current (Eremeev et al. 1992, Oguz et al. 1993).

The meandering and filamenting structure of the Rim Current may realize the water exchanges between shelf and deep waters of the Black Sea (Sur et al. 1994, 1996). Significant quantities of freshwater bearing nutrients, heavy metals, pesticides and hydrocarbons discharged by major rivers (mainly the Danube) are transported along the coast by the meandering boundary current, which may introduce them into the interior of the basin via turbulent exchanges and filament formations. The Danube alone was reported to have introduced $60000 \mathrm{t} \mathrm{yr}^{-1}$ of total phosphorus and about $340000 \mathrm{t} \mathrm{yr}^{-1}$ of total inorganic nitrogen to the northern and northwestern regions of the Black Sea before 1992 (Mee 1992). In contrast, in the southern region of the basin, the major Turkish rivers were estimated to have contributed only $1700 \mathrm{t} \mathrm{yr}^{-1}$ of orthophosphate and $25000 \mathrm{t} \mathrm{yr}^{-1}$ of total inorganic nitrogen in the same period (Sur et al. 1996).

In the light of the above background information, 17 sub-regions including 5 in the open part of the sea, and each having specific characteristics, were identified for the entire Black Sea (Fig. 1A). Regions 1 and 3 correspond to the northern and southern halves of the western cyclonic circulation, respectively; Regions 2 and 4 to the northern and southern halves of the eastern cyclonic circulation, respectively; and Region 5 to the southeastern or Batumi anticyclonic circulation.

The compilation of data on the spatial-temporal distributions of chl $a$ in the open areas of the basin reveal large discrepancies between sub-regions in regard to sampling intensity and coverage for the different interannual periods (Figs. 1B-D \& 2). About $260 \mathrm{chl}$ a measurements were made during the first period (1964 to 1986), more than 600 in the second period (1988 to 1992), and only 150 in the third period (1993 to 1996). Winter data are not numerous for all temporal periods analysed, and the maximal amount of chl a data is for the autumn months. Most of the data for the second period (1988 to 1992) are for September 1991 which covers all 5 regions (3 to 27 measurements in each region), whereas only $2 \mathrm{chl}$ a data sets are available for only 1 region in September 1992. Data for December in the second period are available for only 2 years (1989 and 1991) and within only 1 region. The least uniform and most incomplete data set for $\mathrm{chl} a$ is in the last interannual period (1993 to 1996), for which no chl a data is available over a period of $5 \mathrm{mo}$.

Discrepancies in $\mathrm{PO}_{4}$ and DIPP data in terms of area coverage, seasons and time periods are similar to those for chl a data. These discrepancies in the data coverage create difficulties in presenting a complete picture of seasonal changes for the variables investigated for individual years, as well as long-term changes for separate regions. The biggest problem arose during the determination of longterm variability in DIPP data, since there was only a limited number of DIPP measurements (only 230 data points for both ${ }^{14} \mathrm{C}$ methods) in the open Black Sea for the whole period of investigation. Also, it was necessary to analyse the results of the different ${ }^{14} \mathrm{C}$ methods (SIST and
Fig. 2. Interannual comparison of surface chl $a$ in sub-regions 1 to 5 of the open Black Sea (Fig. 1) in different months 
AIST) separately (Richardson 1991). Therefore, a preliminary evaluation of spatial and temporal changes in the various regions and the entire open Black Sea was carried out for chl a data only.

To assess these changes, the data for the whole open basin and for contrasting regions were compared. A higher anthropogenic impact induced by the Danube, which bears the effluents of 8 European countries, was expected for Region 1, whereas for the last 2 regions (4 and 5), in which the coastal areas are not heavily industrialized, natural variations would be expected to play a greater role in phytoplankton characteristics. The degree of spatial and temporal variability in chl a values was determined using standard parameters of variation: index of variation ( $\mathrm{R}=$ maximum value/minimum value), mean standard deviation (SD) and coefficient of variation $(\mathrm{CV}=\mathrm{SD} / \mathrm{M}$, where $\mathrm{M}$ is the mean value) (Zar 1984, Lakin 1990).

The results of chl a surveys in a single month of the same year were used to estimate spatial variability in Regions 1, 4 and 5. This allowed us to exclude the influences of seasonal and interannual variability. Evaluation of spatial variability within the whole open basin was carried out in the same manner, but in this case joint chl a data set from at least any 3 of 5 regions were used, because the sum of surface area of any 3 regions in the open sea comprises more than $50 \%$ of the whole open sea (Fig. 1A).

To evaluate the long-term variability, the data for separate months and any 1 of 5 regions were used. This allowed us to exclude seasonal and spatial variability. To assess the seasonal variability in chl a levels, we used data for separate regions obtained during 6 to 12 mo, representing all seasons within the same interannual period.

Microsoft Excel, Golden Software Grapher as well as SigmaPlot for Windows and its supplement ANOVA programs were used for the statistical analysis and data processing. The significance of the difference between means was evaluated with the Student's $t$-test (Zar 1984). A significance level of $p \leq 0.05$ was set based on the hypothesis that 'no difference' is assumed to be false. When the level of significance was more than 0.05, the hypothesis of 'no difference' was assumed to be true, and the means were combined. The temporal (monthly and interannual) period derived from such means was considered a quasi-stationary period, i.e. a period exhibiting relatively stable values of the parameters investigated.

For processing our preliminary statistical data, distribution curves of the variation in chl $a_{1}$ DIPP and $\mathrm{PO}_{4}$ were constructed for those data sets for which no less than 20 data points for different months and different interannual periods were available. These curves show a log-normal distribution for $\mathrm{PO}_{4}$ and an almost normal distribution for chl $a$ and DIPP. Other tests for central tendency (mode, median and geometric mean) also confirmed these findings. Thus, the arithmetic mean (M) for the quasi-stationary period was used for chl a and DIPP and the geometrical mean (G) for $\mathrm{PO}_{4}$.

\section{RESULTS}

\section{Surface chlorophyll a}

A comparison of spectrophotometric and fluorometric methods used for chl a determination during the March-April 1999 cruise of the RV 'Vodyanitsky' showed the spectrophotometric chl a (chl-sp) values to be very close to the fluorometric chl a (chl-fl) values (Fig. 3). The results of this comparison and the conclusions of 2 expert working groups (Neveux et al. 1990, Mantoura et al. 1997) allowed us to pool the chl a data obtained by the 2 methods and use them as a single data set without any further correction. The long-term changes in chl a levels were pre-tested by analysing data points for the whole period investigated. However, because of the gaps in the chl a data for winter and the early spring months prior to 1986, interannual variability of surface chl a had to be evaluated using the data for the May to November period in each year (Fig. 4). This analysis revealed 3 interannual periods with different chl a means over the 7 mo period: (1) 1964 to 1986 , with a mean chl a value (M) of $0.15 \pm$ $0.07 \mathrm{mg} \mathrm{m}^{-3}$ (n = 230); (2) 1988 to 1992, with higher concentrations $\left(\mathrm{M}=0.56 \pm 0.19 \mathrm{mg} \mathrm{m}^{-3}, \mathrm{n}=390\right)$; (3) 1993 to $1996\left(\mathrm{M}=0.22 \pm 0.10 \mathrm{mg} \mathrm{m}^{-3}, \mathrm{n}=51\right)$. The identification of interannual periods with different

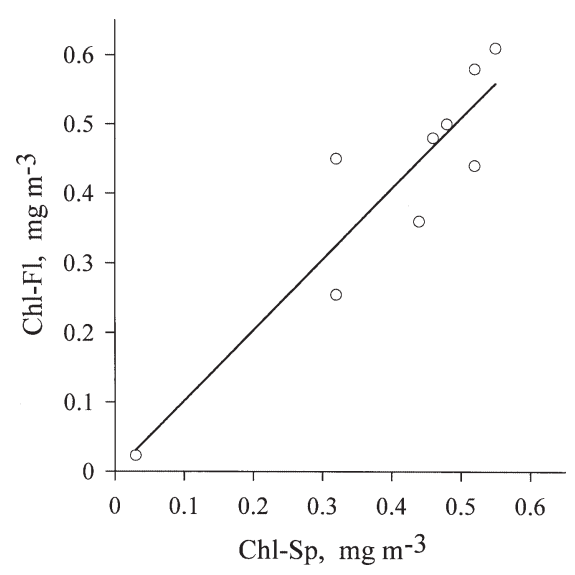

Fig. 3. Comparison of chl a data obtained by Jeffrey \& Humphrey (1975) using spectrophotometry (Chl-Sp) and by JGOFS (1994) using fluorometry (Chl-Fl) during the MarchApril 1999 cruise of RV 'Vodyanitsky'. Equivalence line $y=x$ is plotted. Correlation: $[\mathrm{Chl}-\mathrm{Fl}]=1.02[\mathrm{Chl}-\mathrm{Sp}]+0.0001, \mathrm{r}^{2}=$ $0.84, \mathrm{SD}=0.077 \mathrm{mg} \mathrm{m}^{-3}, \mathrm{CV}=19 \%$ 


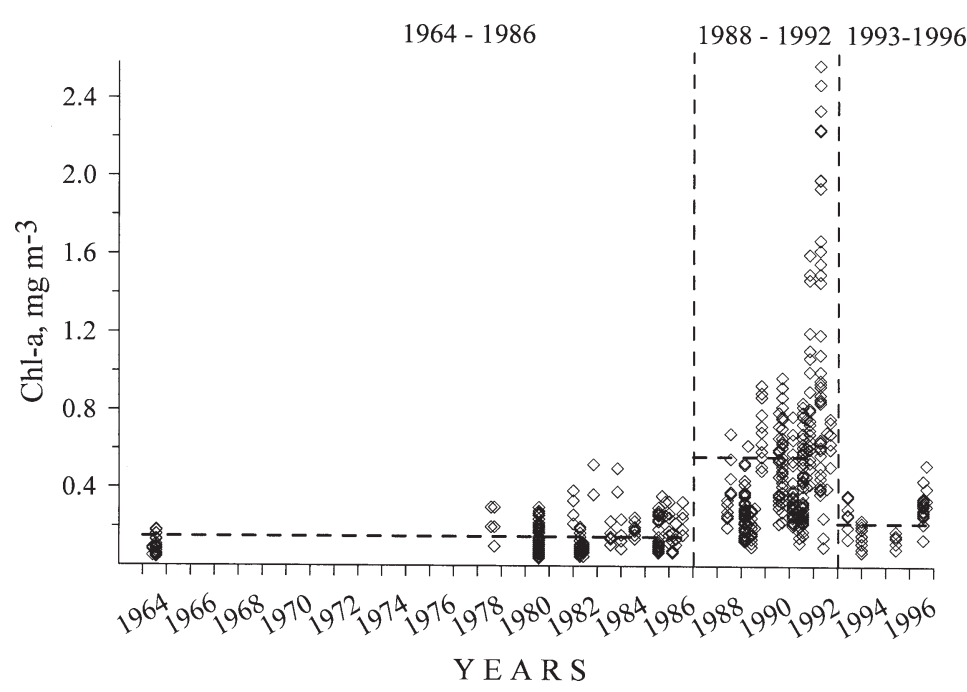

Fig. 4. Long-term changes in chl a levels in the deep Black Sea for May to November. Vertical dashed lines define borders for 3 interannual periods with different means (horizontal dashed lines). Each data point represents a single measurement

mean chl a levels led us to investigate seasonal changes in chl $a$ within these 3 periods.

Comparison of spatial and temporal variability in chl a (Table 2) revealed (1) no statistically significant differences between Region 1 and Regions 4 and 5, and (2) appreciably lower spatial variability for the entire open Black Sea compared to long-term and seasonal variability. These results enabled us to consider the entire open Black Sea as a single water mass for the analysis of long-term and seasonal variability in chl $a$.

The seasonal dynamics of chl a levels for the entire open Black Sea for 3 interannual periods are shown in Fig. 5. The larger data set for the second period (1988 to 1992) allows variations to be more clearly followed. A bi-modal seasonal curve for chl $a$ is clearly evident during this period, with a main winter-spring maximum in February-March $(\mathrm{M}=1.89 \pm 0.75 \mathrm{mg}$ $\left.\mathrm{m}^{-3}\right)$ and a less marked peak in November $(\mathrm{M}=$ $0.76 \pm 0.26 \mathrm{mg} \mathrm{m}^{-3}$ ). The mean chl $a$ value for July was calculated by excluding the data for July $1992\left(\mathrm{M}=1.14 \pm 0.68 \mathrm{mg} \mathrm{m}^{-3}\right)$, which displayed abnormally high summer chl a values.

Fig. 5. Seasonal curves (dashed lines) for chl a values in the open Black Sea in different interannual periods. Each bar represents monthly mean for whole interannual period, except (dashed bar) July 1992. Number of measurements and standard deviation for each month are also shown
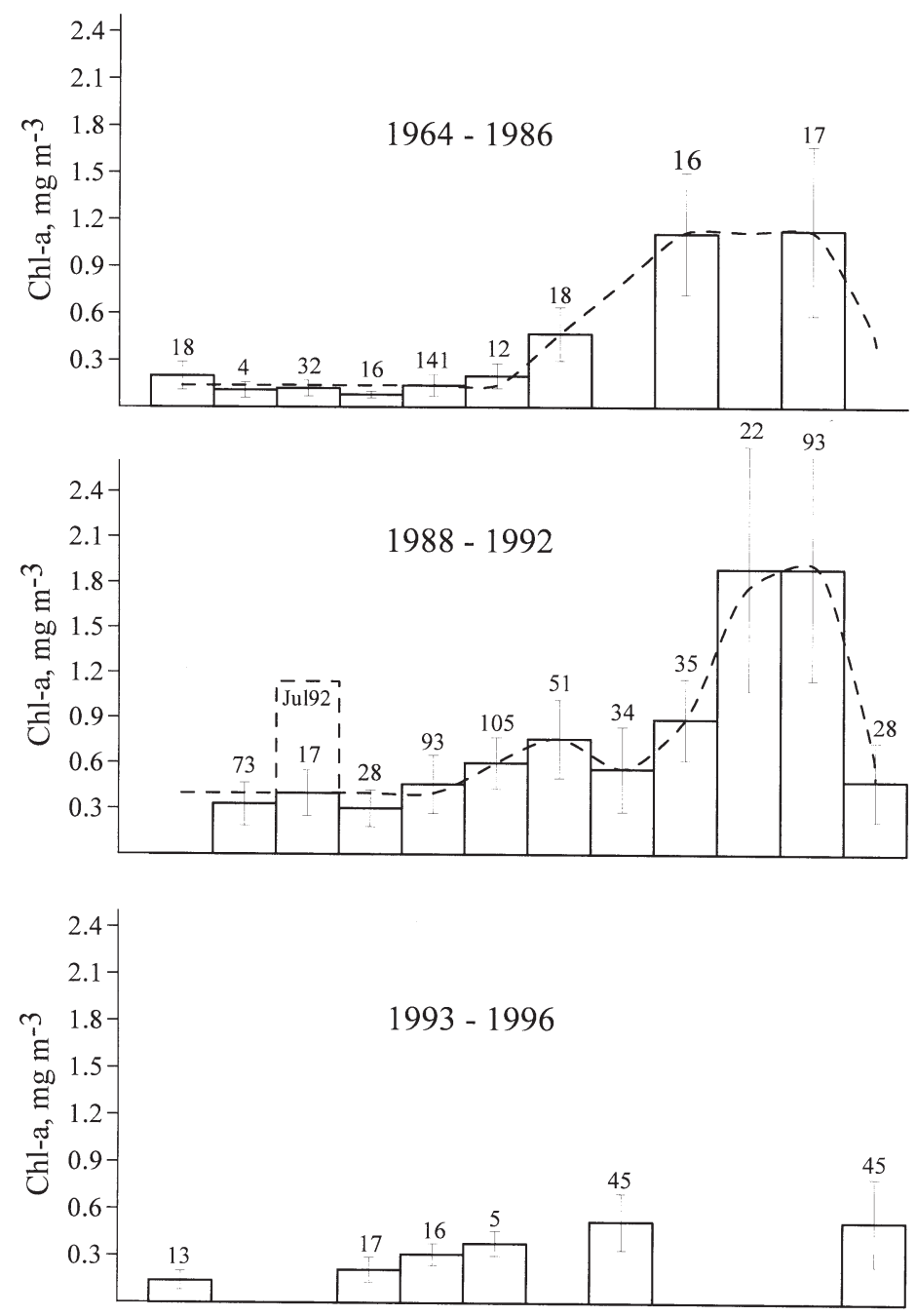

May Jun Jul Aug Sep Oct Nov Dec Jan Feb Mar Apr 
Table 2. Mean (range) spatial and temporal variability in surface chl a in the open Black Sea. n: number of data sets; R: variation index (max/min); SD: mean standard deviation; CV: coefficient of variation (SD/mean, \%)

\begin{tabular}{|lcccc|}
\hline Type of variability & $\mathrm{n}$ & $\mathrm{R}$ & $\mathrm{SD}$ & $\mathrm{CV}$ \\
\hline Spatial variability for Region 1 & $5(11-29)$ & $4.25(2.7-6.1)$ & $0.21(0.07-0.54)$ & $42(25-57)$ \\
Spatial variability for Regions 4 and 5 & $5(7-18)$ & $4.25(2.1-6.3)$ & $0.23(0.03-0.77)$ & $41(23-60)$ \\
Spatial vatiability for entire deep sea & $13(12-93)$ & $3.95(1.9-7.5)$ & $0.14(0.04-0.24)$ & $36(22-55)$ \\
Long-term variability & $4(37-96)$ & $10.8(5.7-21.0)$ & $0.19(0.08-0.24)$ & $50(43-68)$ \\
Seasonal variability & $5(35-147)$ & $19.9(5.8-26.7)$ & $0.40(0.19-0.51)$ & $59(45-64)$ \\
\hline
\end{tabular}

the warm quasi-stationary interval (May to August: $\mathrm{M}=0.18 \pm 0.08 \mathrm{mg} \mathrm{m}^{-3}$ ) was lower than in the second interannual period, but close to the mean value for the first interannual period.

So, the interval from approximately April-May until September-October displayed low chl a levels for all 3 interannual periods. Although the main winter-spring maxima (i.e. January to March) and an additional peak in autumn were evident for the first 2 interannual periods, seasonal variability in chl a was not well marked for the third interannual period (1993 to 1996). It should be noted that very high chl a values in summer were observed only in July 1992, when concentrations in some areas of the open sea increased up to $2.5 \mathrm{mg} \mathrm{m}^{-3}$ (Fig. 4).

The chl a data for the quasi-stationary interval (May to September) for the entire open Black Sea reveal a clear long-term trend (Fig. 6A). Chl a levels were moderate, with a mean value of $0.15 \pm 0.04 \mathrm{mg} \mathrm{m}^{-3}$ within the first 'quiet' 1964 to 1986 period, but increased steadily at a rate of $0.06 \mathrm{mg} \mathrm{m}^{-3} \mathrm{yr}^{-1}$ during 1988 to 1991 and sharply in 1992 (mainly due to high July values) up to $0.99 \pm 0.7 \mathrm{mg} \mathrm{m}^{-3}$. In contrast, negative trends were characteristic of the third

Fig. 6. Long-term variability in surface chl $a$ in the open Black Sea during (A) April to September and (B) October to March. In (A), dashed line shows quasi-stationary interannual period, continuous line steady increase at a rate of $+0.06 \mathrm{mg} \mathrm{m}^{-3} \mathrm{yr}^{-1}$ from 1988 to 1991 and sharp increase in 1992, as well as abrupt decrease in 1993 and a negative trend $\left(-0.02 \mathrm{mg} \mathrm{m}^{-3} \mathrm{yr}^{-1}\right)$ from 1993 to 1996. In (B), dashed lines indicate different monthly intervals from October to March, continuous line increase in chl a during winter-spring phytoplankton bloom in the second period (1988 to 1992) compared first period (1964 to 1986). Number of measurements and standard deviations are also shown period (1993 to 1996): an abrupt decrease in chl a down to $0.26 \pm 0.08 \mathrm{mg} \mathrm{m}^{-3}$ in 1993 and a negative trend $\left(-0.02 \mathrm{mg} \mathrm{m}^{-3} \mathrm{yr}^{-1}\right)$ during 1993 to 1996.

The gradual increase in chl a levels from summer to winter/spring (Fig. 5) led us to analyse the long-term trends in chl a levels in detail for the cold period of the year (October to March) (Fig. 6B). It was easier to trace long-term monthly changes in chl a levels by dividing the cold period into 3 subperiods: (1) a period with low chl a levels (0.4 to $0.8 \mathrm{mg} \mathrm{m}^{-3}$ in October to December), (2) a winter-spring bloom period with high chl a levels
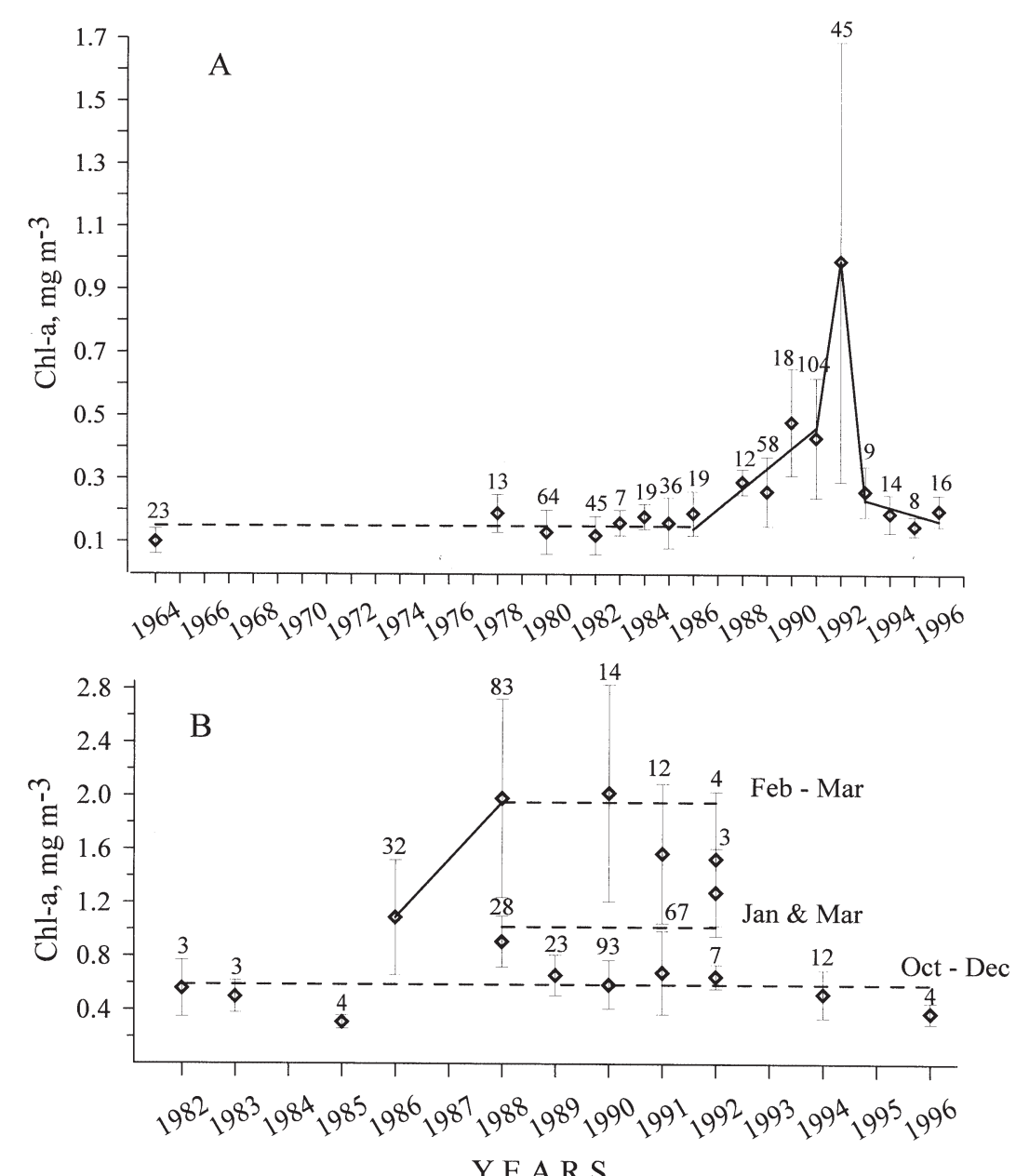

Y E A R S 
Table 3. Seasonal patterns of depth-integrated primary production, DIPP $\left(\mathrm{mg} \mathrm{C} \mathrm{m}^{-2} \mathrm{~d}^{-1}\right)$ obtained by actual (DIPP $\left.\mathrm{AIST}\right)$ and simulated (DIPP $\mathrm{SIST}_{\text {T }}$ ) in situ ${ }^{14} \mathrm{C}$ methods during the second interannual period (1988 to 1992). Data expressed as the monthly interval mean of DIPP \pm SD, with number of DIPP measurements in parentheses. nd: no data

\begin{tabular}{|lcc|}
\hline Patterns & DIPP $_{\text {AIST }}$ & DIPP $_{\text {SIST }}$ \\
\hline Winter/spring maximum & $410 \pm 190(24)$ & $550 \pm 258(35)$ \\
Summer maximum & $363 \pm 125(23)$ & $587 \pm 135(31)$ \\
Lowest annual values & $274 \pm 139(23)$ & nd \\
Winter/spring:summer maxima ratio & 1.1 & 0.9 \\
Annual maximum:minimum ratio & 2.4 & nd \\
\hline
\end{tabular}

The presence of 2 DIPP maxima (summer and winter-spring) together with the observed intervals with low DIPP values (April-May and September to February, with $\mathrm{M}_{\text {AIST }}=274 \pm 139 \mathrm{mg} \mathrm{C} \mathrm{m}^{-2} \mathrm{~d}^{-1} ; \mathrm{n}=$ 23) necessitated a separate evaluation for the long-term variability for different monthly intervals (Fig. 9). As clearly seen from Fig. 9, the number of DIPP data for each monthly interval was not sufficient to characterize its interannual and long-term variability in the open regions of the Black Sea in terms of both ${ }^{14} \mathrm{C}$ methods.

(>1.5 $\mathrm{mg} \mathrm{m}^{-3}$ in February-March), and (3) a period displaying transitory levels ( 0.8 to $1.5 \mathrm{mg} \mathrm{m}^{-3}$ in January and March) within the cold season. Examination of Fig. 6B reveals the absence of regular long-term trends in chl a levels during the investigated period for the cold season of the year, with the exception of an increase in chl a during the winter-spring maximum (February-March) in the second interannual period compared to that (January and March) in the first period (Fig. 5).

\section{Depth-integrated primary production}

Evaluation of the long-term changes in DIPP values separately for DIPP AIST $_{\text {and DIPP }}$ SIST using the data for May to November each year for the whole investigation period also indicated the presence of 3 interannual periods similar to those for the chl a data (Fig. 7). The first period (1980 to 1985) had mean (M) DIPP values of $\mathrm{M}_{\mathrm{AIST}}=169 \pm 57 \mathrm{mg} \mathrm{C} \mathrm{m}^{-2} \mathrm{~d}^{-1}(\mathrm{n}=17)$ and $\mathrm{M}_{\mathrm{SIST}}=112$ $\pm 54 \mathrm{mg} \mathrm{C} \mathrm{m}^{-2} \mathrm{~d}^{-1}(\mathrm{n}=59)$; the second period (1986 to 1992) displayed higher DIPP means of $\mathrm{M}_{\text {AIST }}=330 \pm$ $140 \mathrm{mg} \mathrm{C} \mathrm{m}^{-2} \mathrm{~d}^{-1}(\mathrm{n}=45)$ and $\mathrm{M}_{\mathrm{SIST}}=587 \pm 135 \mathrm{mgC}$ $\mathrm{m}^{-2} \mathrm{~d}^{-1}(\mathrm{n}=31)$; and the period after 1992 had a mean DIPP value of $271 \pm 67 \mathrm{mg} \mathrm{C} \mathrm{m}^{-2} \mathrm{~d}^{-1}(\mathrm{n}=9)$ according to AIST data.

A seasonal DIPP pattern was obtained only for the second interannual period (1986 to 1992) because of the availability of data for both ${ }^{14} \mathrm{C}$ methods during this period (Fig. 8). There were 2 clearly visible maxima in the DIPP level, one in the summer period $\left(\mathrm{M}_{\mathrm{AIST}}=363\right.$ and $\mathrm{M}_{\mathrm{SIST}}=587 \mathrm{mg} \mathrm{C} \mathrm{m}^{-2} \mathrm{~d}^{-1}$ ) and the other in the February-March interval $\left(\mathrm{M}_{\mathrm{AIST}}=410\right.$ and $\mathrm{M}_{\mathrm{SIST}}=550 \mathrm{mgC}$ $\mathrm{m}^{-2} \mathrm{~d}^{-1}$ ) (Table 3). The lowest DIPP values (234 \pm $30 \mathrm{mg} \mathrm{C} \mathrm{m}^{-2} \mathrm{~d}^{-1}$ ) were obtained in November (all from

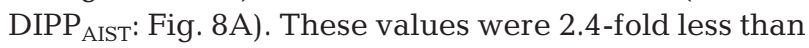
the maximal values during the year (again from AIST: Table 3). Transitory levels between low autumn-winter and high winter-spring bloom values were observed in January, when $\mathrm{M}_{\text {SIST }}$ was $321 \pm 170, \mathrm{n}=9$ (Fig. 8A).
Since there are many gaps in the measured DIPP data in terms of seasonal and, especially, long-term variability, the relationship between DIPP and the more numerous chl a data was evaluated (Fig. 10, Table 4). The large scatter in the data (Fig. 10) do not allow the calculation of a DIPP:chl a ratio which could be used to determine interannual and long-term fluctuations and trends in DIPP. Moreover, comparison of the regression lines for separate seasons indicates significant differences between summer and other seasons for both ${ }^{14} \mathrm{C}$ methods (Table 4). This is in agree-
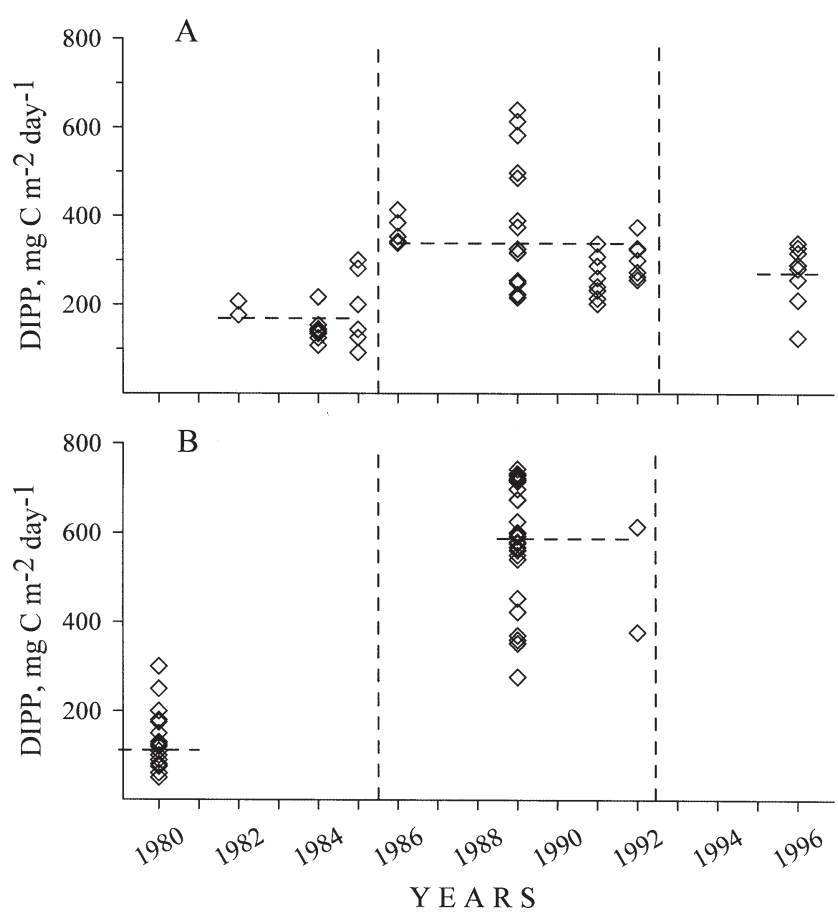

Fig. 7. Long-term changes in depth-integrated primary production (DIPP) in the open Black Sea during May to November measured by (A) actual (DIPP AIST $_{\text {) }}$ and (B) simulated $\left(\mathrm{DIPP}_{\mathrm{SIST}}\right)$ in situ ${ }^{14} \mathrm{C}$ methods. Vertical dashed lines define borders of 3 interannual periods with different mean DIPP values (horizontal dashed lines). Each data point represents a single DIPP measurement 

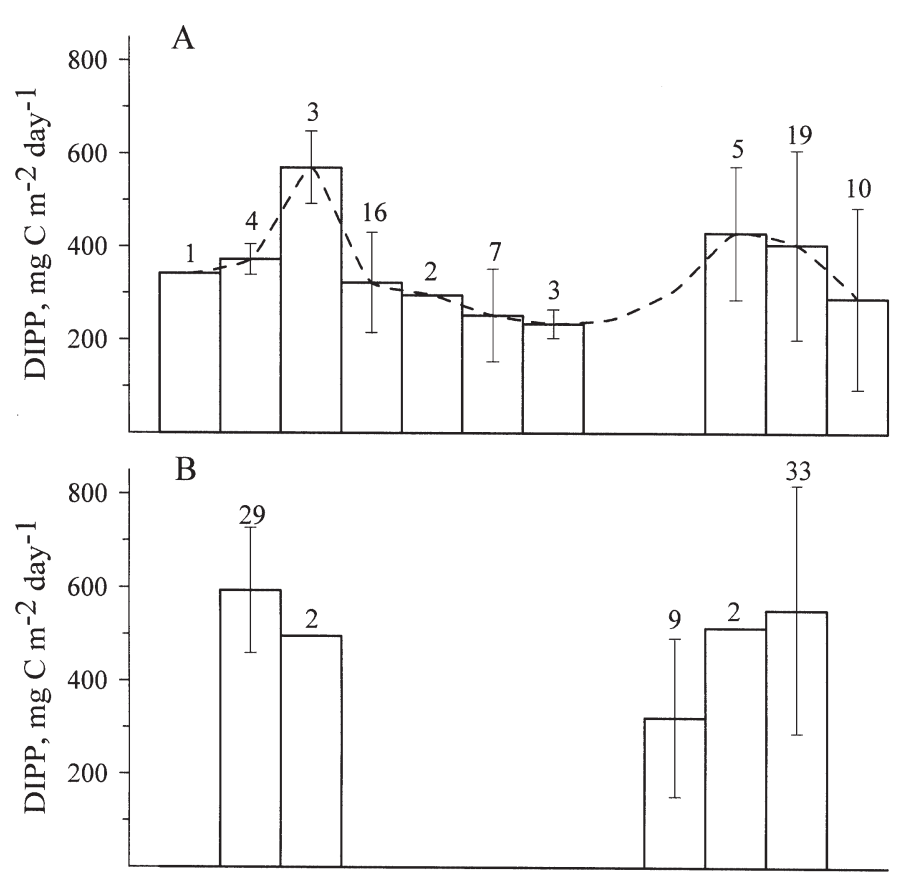

May Jun Jul Aug Sep Oct Nov Dec Jan Feb Mar Apr

Fig. 8. Seasonal curve (dashed line) of DIPP in the open Black Sea during the second interannual period (1986 to 1992) derived from AIST data (A). (B) Seasonal changes derived from SIST data during same interannual period. Each bar represents monthly mean for all interannual periods. Number of measurements and standard deviations are also shown
November to March, with respective geometric means of $0.05 \mu \mathrm{M}(\log \mathrm{G}=-1.35 \pm 0.47, \mathrm{n}=529)$ and $0.10 \mu \mathrm{M}(\log \mathrm{G}=-1.0 \pm 0.49, \mathrm{n}=271)$ for the 1988 to 1992 period and $0.04 \mu \mathrm{M}(\log \mathrm{G}=-1.39 \pm$ $0.48, \mathrm{n}=834)$ and $0.078 \mu \mathrm{M}(\log \mathrm{G}=-1.11 \pm 0.53, \mathrm{n}$ $=403$ ) for the 1964 to 1995 period. Note the unusually high $\mathrm{PO}_{4}$ concentration $(0.21 \mu \mathrm{M})$ in March of the second interannual period.

Statistical analysis of long-term variability in $\mathrm{PO}_{4}$ for 2 periods of the year did not establish any long-term trend (Fig. 12). All monthly mean $\mathrm{PO}_{4}$ values, for the different years, were very low $(0.015$ to $0.138 \mu \mathrm{M})$ with a large scatter in the data (coefficients of variation: 30 to $60 \%$ for $\log G_{;} 100$ to $160 \%$ for $\mathrm{M})$.

\section{DISCUSSION}

The seasonal pattern in chl a levels in the first 2 periods (Fig. 5) obtained using the data set for the entire open Black Sea agrees both with the results for the third period (1993 to 1996) and the results of earlier investigations in various deep areas of the basin (Yunev et al. 1987, Vedernikov 1989, Yunev 1989, Krupatkina et al. 1990, Vedernikov 1991, Berseneva 1993, Vedernikov \& Demidov 1993, ment with the seasonal dynamics: seasonal changes in chl $a$ and DIPP in the open Black Sea displayed identical trends in the cold months but different trends during the summer (Figs. 5 \& 8). Statistically significant differences were also obtained for monthly interval regression lines calculated for AIST and SIST data separately (Fig. 10).

\section{Temporal variations in phosphate concentrations of the upper 0 to 25 m layer}

A curve of the seasonal changes in $\mathrm{PO}_{4}$ levels was constructed for the second interannual period (1988 to 1992) only, because most of the data available was for this period (dashed line in Fig. 11). The overall seasonal variability in $\mathrm{PO}_{4}$ for the whole period (1964 to 1995) is also shown because of the lack of sufficient data for all seasons in the first (1964 to 1986) and third (1993 to 1995) interannual periods, and does not differ greatly from that for the second period.

There are 2 clear curves for $\mathrm{PO}_{4}$ levels for the intra-annual periods April to September and
A

$1980-1986 / 1988-1992 / 1993-1996$

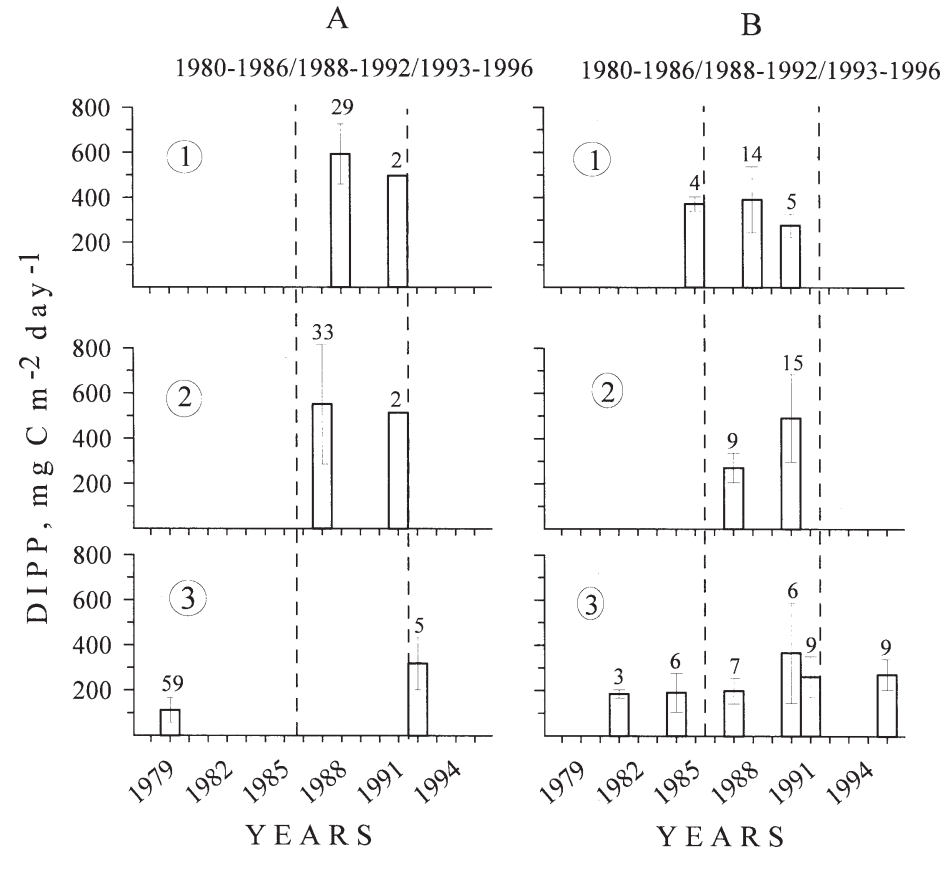

Fig. 9. Long-term variability of DIPP in the open Black Sea measured by SIST (A) and AIST (B) for different monthly intervals: June to August (1), February to March (2), April to May and September to December (3). Each bar represents mean for monthly interval within interannual period. Number of measurements and standard deviations are also shown 


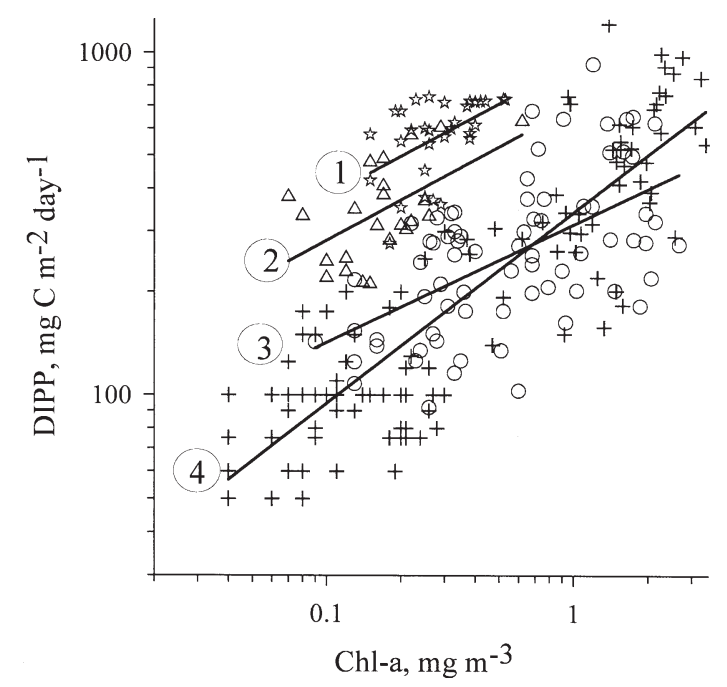

Fig. 10. Relationship between DIPP measured by $2{ }^{14} \mathrm{C}$ methods and surface chl $a$ in the open Black Sea during different monthly intervals: June to August by SIST (k, Line 1) and AIST ( $\Delta$, Line 2); September to December and January to May by AIST $(0$, Line 3$)$ and SIST $(+$, Line 4$)$

Yilmaz et al. 1998b). It should be noted that abnormally high chl a values in July 1992 were not considered as typical of seasonal variations in chl a values because they were observed in the open Black Sea only once during the investigation period.

The observed seasonal pattern of chl a distribution in the open Black Sea fits the bi-modal curve of seasonal chl a dynamics typical for temperate and subtropical waters (Ryther \& Yentsch 1958, Menzel \& Ryther 1960, Matsudaira 1964, Curl \& Small 1965, Williams \& Murdoch 1966, Becacos-Kontos 1977, Eppley et al. 1977, Raymont 1980), as well as the main mode for the winter period in the transition zone in the North Atlantic Ocean observed in satellite data (Banse \& English 1994).

In contrast to chl a variations, the seasonal dynamics of DIPP showed a significant increase in summer months in addition to the winter-spring maximum (Fig. 8). Seasonal dynamics were clear only for the second interannual period for the AIST data (Fig. 8A) for which data covering many months are available. There are few SIST data but on the whole the data available for the summer and winter-spring periods during the same interannual period (Fig. 8B) do not contradict the results obtained with AIST data.

The AIST method revealed similar summer and winter-spring DIPP maxima (average $=387 \mathrm{mgC}$ $\mathrm{m}^{-2} \mathrm{~d}^{-1}$ ), as did the SIST data (average $=569 \mathrm{mgC}$ $\mathrm{m}^{-2} \mathrm{~d}^{-1}$ ) (Table 3). The differences between seasonal patterns obtained by the 2 methods (SIST exceeded AIST data by approximately 30 and $60 \%$ during summer and winter-spring maxima, respectively) were less than those between maximum and minimum monthly mean values during the year (Table 3).

The analysis of seasonality in chl $a_{1}$ DIPP and $\mathrm{PO}_{4}$ allowed us to define quasi-stationary intervals within a year and also to investigate long-term variability in chl $a$ and $\mathrm{PO}_{4}$ separately for each monthly interval. It enabled us to eliminate, to some extent, the 'masking' effect of seasonal changes in the characteristics of the phytoplankton community, which are significant in temperate latitudes (Finenko 1979, Raymont 1980, Chebotarev et al. 1983, Vedernikov at al. 1983, Vedernikov \& Demidov 1993).

Of the 2 phytoplankton characteristics examined (chl $a$ and DIPP), long-term trends could be obtained only for chl a (Fig. 6), for which data were available for all periods of the investigation from different regions in
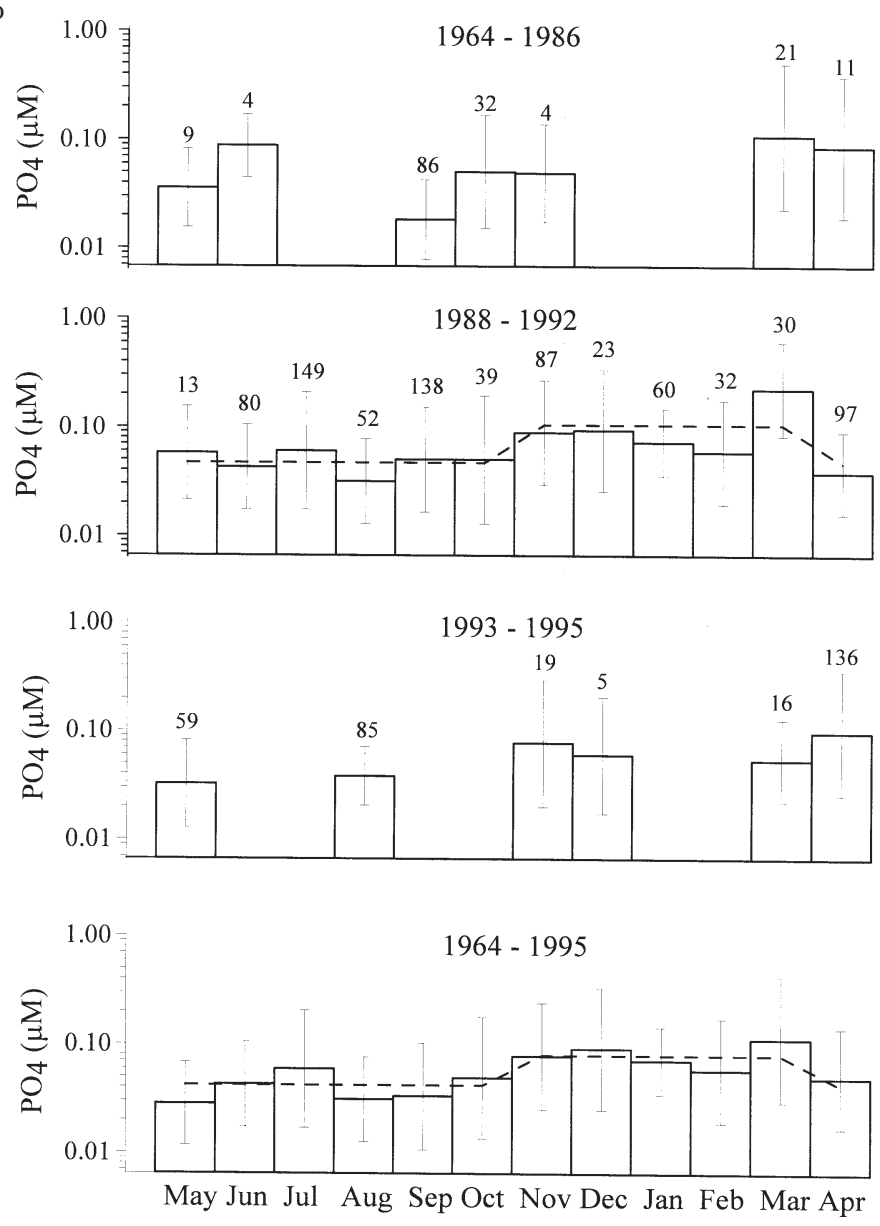

Fig. 11. Seasonal curves (dashed lines) for phosphate concentrations averaged for the upper $25 \mathrm{~m}$ layer of the open Black Sea for different interannual periods. Each bar represents the monthly geometrical mean for the entire interannual period. Number of measurements and standard deviations are also shown 
Table 4. Statistical parameters of $[\mathrm{DIPP}]=a \times[\mathrm{chl} a]+b$ relationship for different monthly intervals with the $2{ }^{14} \mathrm{C}$ methods . r: correlation coefficient; SD: mean standard deviation of [DIPP(chl a)] function; CV: variation coefficient; n: number of measurements. $\mathrm{p}<0.001$ in all cases

\begin{tabular}{|llcccrrrr}
\hline Monthly interval & Method & $a$ & $b$ & r & SD & CV & $n$ \\
\hline June-August & AIST & 718 & 229 & 0.62 & 99 & 27 & 23 \\
\multirow{3}{*}{ September-May } & SIST & 703 & 376 & 0.53 & 117 & 20 & 31 \\
& AIST & 119 & 201 & 0.51 & 142 & 48 & 73 \\
& SIST & 238 & 93 & 0.82 & 144 & 51 & 108 \\
\hline
\end{tabular}

the open Black Sea. A positive correlation $(\mathrm{r}=0.51$ to 0.82, p < 0.001) was found between DIPP (by both ${ }^{14} \mathrm{C}$ methods) and the more plentiful chl a data for different monthly intervals (Table 4), indicating that the patterns in long-term variability observed for chl a may also be valid for DIPP.

Interannual fluctuations in chl a are more pronounced during the warm months, approximately from May until September (Fig. 6). During this period of relatively stable chl a concentration, thermal stratification enhances the density stratification in the upper layer of the open Black Sea, preventing the penetration of the nutrient-rich mid-layer waters into the surface waters that are already nutrient-depleted after the winterspring phytoplankton bloom (Sorokin 1983, Vinogradov et al. 1992). Phytoplanktonic populations under nutrient-deficient conditions may be more sensitive to environmental changes and manifest this in changes in their structural and functional characteristics.

In contrast, during the cold months of the year, a decrease in surface-water temperature to $6-8^{\circ} \mathrm{C}$ coupled with increased density triggers intense convectional mixing down to almost 80 to $100 \mathrm{~m}$, a depth which coincides with the permanent pycnocline in the open Black Sea (Ovchinnikov \& Popov 1987). This vertical mixing increases nutrient input into the euphotic zone. Since phytoplankters do not suffer from nutrient deficiency, the effects of changes in environmental factors on their chl a level and, perhaps, on their photosynthetic rate are less pronounced during this period (Fig. 6B).

Unlike chl $a$, no clear trend was seen in the longterm changes of $\mathrm{PO}_{4}$ concentration in the upper $25 \mathrm{~m}$ layer of the open Black Sea during the cold and warm seasons of all periods investigated (Fig. 12). This was confirmed by statistical analysis. The phosphate concentration in the upper part of the euphotic zone remains low (0.015 to $0.138 \mu \mathrm{M})$ throughout the year (Fig. 11).

However, a pronounced increase in the nitrate concentration below the euphotic zone from the late 1960s to the mid-1980s has been reported (Codispoti et al. 1991, Tugrul et al 1992), and a sim- ilar increase in ammonia levels in the anoxic zone has recently been discussed by Konovalov \& Murray (2001). This increase in inorganic nitrogen content appears to nearly equal the increase in the riverine loads into the basin. At the same time, phosphates below the euphotic zone have not shown any long-term variability during the period investigated (Konovalov et al. 1999). The phosphate concentration at the $\sigma_{t}=15.70$ and $\sigma_{t}=16.40$ density interfaces has increased by less than $20 \%$, which is close to the variations recorded in individual cruises. The ratio of the increase in the phosphate level to that of inorganic nitrogen appears to be 1:16, suggesting that a higher increase in phosphate concentrations is hardly possible, as any sources of phosphate, other than mineralization of detritus are unknown.
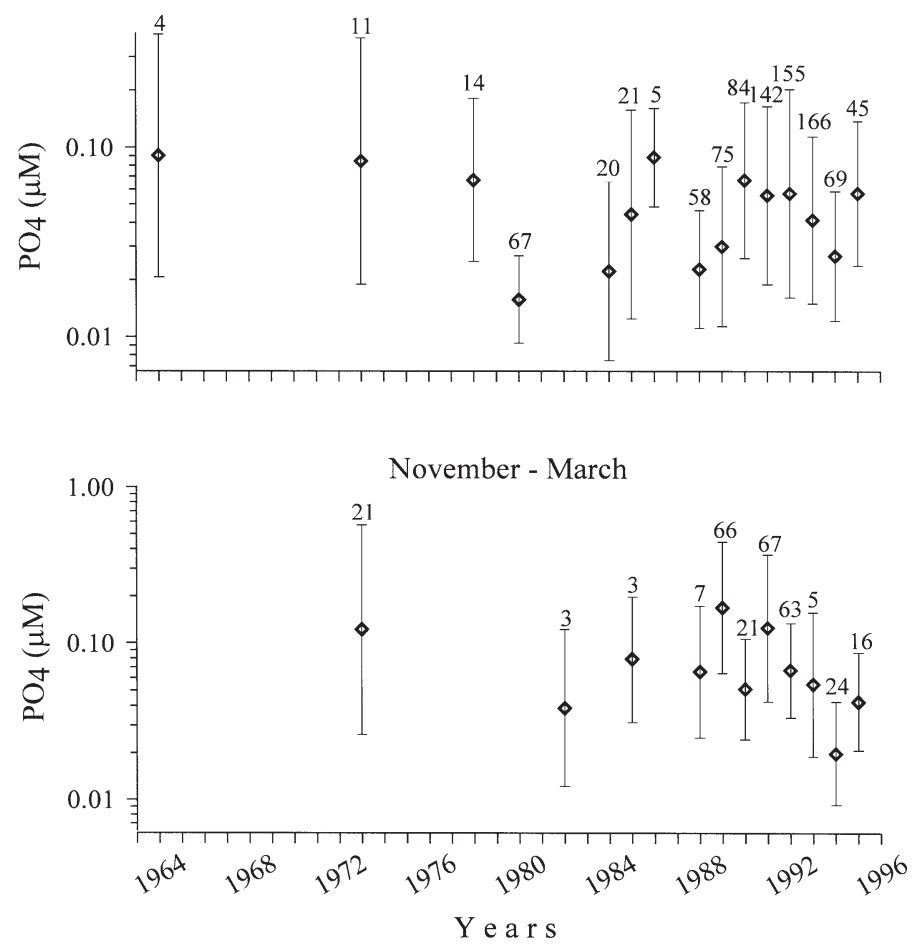

Fig. 12. Long-term variability in phosphate concentrations averaged for the upper $25 \mathrm{~m}$ layer of the open Black Sea for 2 different monthly intervals. Each point represents geometrical mean for entire monthly interval. Number of measurements and standard deviations are also shown 
These variations together with changes in the distribution of oxygen and hydrogen sulfide have been used by Konovalov \& Murray (2001) to exemplify the quantitative aspects of anthropogenic effects on the eutrophication and hence the chemical structure of the whole basin rather than of specific coastal regions. If the fact of anthropogenic eutrophication is accepted, then the absence of statistically reliable changes in the distribution of phosphate in the upper $25 \mathrm{~m}$ layer on the time scale of decades can be explained by an effective removal of phosphate from the euphotic zone. The ratio of the inorganic nitrogen load to that of phosphate, which exceeds considerably the accepted ratio of 16 (Cociasu et al. 1996), suggests a phosphorus deficit in primary biological processes. The low phosphate concentrations and the absence of statistically reliable trends in the distribution of phosphate in the upper $25 \mathrm{~m}$ layer suggest $\mathrm{PO}_{4}$ limitation at the primary production level throughout the whole of the second annual period (the mid-1980s and early 1990s). Such limitation would not of course mean an absolute limitation in primary production, but rather the dependence of primary production on the phosphate load compared to that of any other nutrient element. These findings show that phosphate concentrations in the upper 25 m layer cannot be considered a reliable indicator of the presence or absence of anthropogenic eutrophication in the Black Sea.

In summary, we can conclude that there has been no significant trend in surface chl $a$ and depth-integrated primary production levels within the upper portion of the euphotic zone of the open Black Sea during the cold season over the last 3 to 4 decades. On the other hand, the phytoplankton characteristics we investigated displayed a highly significant positive interannual trend during the warm season for the second half of the 1980s to the beginning of the 1990s, followed by a negative trend after 1992 .

Adverse changes in the Black Sea ecosystem started to be apparent in the late 1960s to early 1970s, especially in coastal areas of the northern and western parts of the basin (Balkas et al. 1990, Mee 1992, Zaitsev 1993, Volovik et al. 1993, Kideys 1994, Niermann et al. 1994, Cociasu et al. 1996, Zaitsev \& Alexandrov 1997, Petranu et al. 1999). These have been manifested particularly in a reduction in the biodiversity (for both plant and animal species) and a decrease in the biomass and changes in specific composition of both plankton and fishes. These changes were related to changes in nutrient concentrations, chemical and oil pollution, eutrophication, and other anthropogenic impacts such as dumping, dredging, and the damming of rivers.

At the same time, there was no evidence of a negative shift in the plankton and fish communities in the open Black Sea during the 1960s to mid-1980s (Mee
1992, Niermann et al. 1999, Vinogradov et al. 1999, Kideys et al. 2000), except for fluctuations in zooplankton densities in the deep eastern region of the sea (Kideys et al. 2000), and a detectable increase in the summer biomass of phytoplankton since the beginning of the 1970s in offshore regions of the Black Sea (Vinogradov et al. 1999). In the present investigation, variability in the chl a level of the open regions of the basin clearly showed that the interannual period of 1964 to 1986 was a moderate period with low surface chl a levels during the warm months (Fig. 6).

On the other hand, appreciable changes in the hydrochemical structure of the open Black Sea already occurred in the 1970s. Observations indicated a noticeable increase in nutrient and sulfide concentrations within the anoxic layer coincident with significant changes in the hydrochemical characteristics of the upper layer (Tugrul et al. 1992, Cociasu et al. 1996, Humborg et al. 1997). Within the oxic layer, the level of nitrate increased by 2 - to 3 -fold from the late 1960 s to the 1980s (Codispoti et al. 1991, Tugrul et al. 1992), while concentrations of ammonia and silica decreased considerably during approximately the same period (Tugrul et al. 1992, Humborg et al. 1997).

A decrease in ammonia and silicate in the oxic layer, and low phosphate concentrations in the upper layer of the euphotic zone throughout the year (Fig. 11), together with the dramatic increase in nitrate concentration supports the idea that the Black Sea ecosystem has changed from nitrogen-limited primary production to phosphorus and/or silicate limited production (Mee 1992, Tugrul et al. 1992, Konovalov et al. 1999). Moreover, the high correlation of variations in nitrate concentrations within the oxic and suboxic layers with variations in apparent oxygen utilization supports the hypothesis that, prior to the 1980s, these changes occurred in the open Black Sea as a result of eutrophication (Konovalov et al. 1999). Here it should be noted that, since 1983, there has been a small but statistically significant gradual increase in depth-integrated chl a in the open sea, in contrast to surface chl a (Yunev unpubl. data). This is in accordance with evident changes in the chemical structure. Thus, the mean depth-integrated chl a averaged $16.1 \mathrm{mg} \mathrm{m}^{-2}$ in the warm months before 1982, but about $22.8 \mathrm{mg} \mathrm{m}^{-2}$ during 1983 to 1986.

Sudden and drastic changes in the Black Sea ecosystem, i.e. a drastic decline in the Black Sea fishery, dramatic changes in the zooplankton biomass, a sharp decline in anchovy eggs and larvae, and a large decrease in water transparency occurred in the second half of the 1980s (Mee 1992, Vinogradov et al. 1992, Caddy 1993, Kideys 1994, Mutlu et al. 1994, Niermann et al. 1994, Gucu 1997, Vladimirov et al. 1997, Konsulov \& Kamburska 1998, Kovalev et al. 1998, Shiganova 1998, 
Shiganova et al. 1998, Vinogradov et al. 1999). Besides these ecological modifications, additional pressures imposed by the accidentally introduced ctenophore Mnemiopsis leidyi and overfishing have resulted in drastic shifts in the pelagic communities of the Black Sea. These negative forces on the main components of pelagic community and on fisheries resources remained effective until about the early 1990s.

Since 1992, however, the pelagic ecosystem of the open Black Sea has shown positive signs of recovery. The abundance of ichthyoplankton and zooplankton, and species diversity in the period 1995 to 1996 in the northern Black Sea increased to levels higher than those observed in the 1992 to 1993 period, whilst the number of Mnemiopsis leidyi decreased to moderate levels (Shiganova 1998). Higher abundance and increase in species diversity of ichthyoplankton and zooplankton were also recorded in the southern Black Sea (Shiganova et al. 1998, Kideys et al. 1999). The total Black Sea anchovy catch in 1995 (400639 t) almost reached the same level as in the thriving period of the mid-1980s (449581 t) (MacLennan et al. 1997). Water transparency in terms of annual mean Secchi disk depth has also increased in the open waters from about $6 \mathrm{~m}$ in 1992 (minimal mean annual value for the period from 1920) to $14 \mathrm{~m}$ in 1995, i.e. close to the level measured before 1985 (15 to $16 \mathrm{~m}$ : Vladimirov et al. 1997).

Hydrochemical observations have also revealed positive tendencies since 1992: concentrations of nitrate have decreased considerably, and that of silicate has increased in the oxic zone and decreased in the anoxic zone of the Black Sea (Konovalov et al. 1999). These results are in agreement with recent observations of a low $\mathrm{NO}_{3}: \mathrm{PO}_{4}$ ratio in the waters of the chemocline during the 1995 to 1996 period (Yilmaz at al. 1998), and bioassay tests in 1998 and 1999 showed that nitrogen is limiting nutrient for the central deep part of the Black Sea during the warm period, while phosphorus is still the limiting nutrient for those coastal regions with riverine input (Yayla et al. 2001).

The above mentioned changes in mezozooplankton, ichthyoplankton and fish resources agree well with the data on interannual variability after 1986 in the phytoplankton characteristics investigated. These variations, in turn, were reflected as a positive trend in the warm months of the 1988 to 1992 period, and as a negative trend in the 1993 to 1996 period for surface chl $a$ (Fig. 6A), as well as for depth-integrated chlorophyll (Yunev unpubl. data). The observation of a positive significant correlation between chl a and DIPP (Table 4) also indicates similar tendencies in interannual changes for primary production during this period.

As stated above, an increasing trend in total phytoplankton biomass in summer has been apparent since the beginning of the 1970s in offshore regions of the
Black Sea (Vinogradov et al. 1999), but it has fluctuated at evidently high levels, especially since 1985 (Mikaelyan 1996). Interannual changes were detected not only in biomass, but also in the size and taxonomic structure of the phytoplanktonic community. The summer phytoplankton population has gradually changed to one of rather small-sized species since about 1986, with coccolithophores (mainly Emiliana huxleyi) and small flagellates prevailing in certain periods (Mankovsky et al. 1996). This was especially notable in the summer of 1992, when coccolithophores made up $91.4 \%$ of the total phytoplankton compared to $45.5 \%$ in 1991 (Mankovsky et al. 1996) and only 20\% before 1986 (Georgieva 1993). An extremely intense bloom of small phytoplankters during the summer of 1992 (Mankovsky et al. 1996) resulted from a sharp increase in chl a levels (Fig. 6A) during the second interannual period, as discussed earlier.

It is remarkable that, despite an increase in phytoplankton biomass, the biomass of herbivorous copepods declined (Shiganova et al. 1998). Even in bulk, algae of too small a size are not a suitable food for copepods, especially Calanus euxinus, which is predominant in the open Black Sea (Petipa 1981, Vinogradov et al. 1992).

At the same time, a similar decrease in zooplankton biomass and small pelagic fish stocks from the second half of the 1980s until the beginning of the 1990s was also observed in other World Ocean areas (Baltic Sea, North Sea, Atlantic and Pacific Oceans) and in some European freshwater lakes (Mann 1993, Klyashtorin \& Rukhlov 1998, Niermann et al. 1999). These changes were associated with major changes in the atmospheric and hydrological regimes of all these basins related to large-scale oscillation systems such as the NAO (North Atlantic Oscillation), SO (Southern Oscillation), ENSO (El Niño Southern Oscillation), and ALPI (Aleutian Low Pressure Index) (Niermann et al. 1999). The global atmospheric changes in the second half of the 1980s have resulted in changes in river runoff, salinity, sea and air temperature, atmospheric pressure, precipitation and the strength of westerly winds throughout the entire northern hemisphere (Ozsoy \& Unluata 1997, review by Niermann et al. 1999)

The various reasons for the changes in the Black Sea ecosystem during the end of the 1980s and the beginning of the 1990s are still being discussed. Both regional (increased eutrophication and pollution, overfishing, outburst of the alien predator Mnemiopsis lei$d y i$, etc.) and climatic factors are being examined (see reviews by Shiganova 1998, Niermann et al. 1999, Vinogradov et al. 1999). Niermann et al. (1999) suggested that man-made and natural environmental impacts on the Black Sea ecosystem have had cumulative effect. Increasing euthrophication since the end of 
the 1960s has driven the pelagic ecosystem into an unsteady state with disturbed prey-predator relationships. It required only a triggering mechanism for the outburst of the alien ctenophore Mnemiopsis leidyi, which was then favored by the altered trophic structure. This triggering effect could have been a climatic signal during or at the end of the 1980s. Additionally, changes in the chemical structure of the open Black Sea waters were clearly evident by the 1980s (Konovalov et al. 1999) as well as a step-by-step increase in depth-integrated chl a values in the open sea since 1983 (Yunev unpubl. data). Both of these may be attributable to anthropogenic eutrophication. Perhaps the anthropogenic impact had become so heavy by this period that the Black Sea pelagic ecosystem was more susceptible to climatic changes than in previous years.

Acknowledgements. This work could not have been realised without the support of NATO through the Linkage Grant ENVIR.LG 973350. Our thanks go to Professor Umit Unluata, NATO TU-BLACK SEA Project Director, whose brilliant managerial talent resulted in the Black Sea Database through the significant collaborative effort of marine scientists from all the Black Sea riparian states. Furthermore we would like to thank Dr Zosim Finenko for his constructive criticism, Dr Victor Nikolsky for his statistical advice, Dipl-Ing. Ludmila Galkovskaya for her help in preparing data sets from TU-BS DB, and Mrs Alison M. Kideys for improving the English text. Our especial gratitude to 4 anonymous reviewers, whose valuable comments greatly improved an earlier version of the manuscript. Some of the data used in this publication originates from the Database prepared within the framework of the NATO TU Black Sea Project.

\section{LITERATURE CITED}

Balkas T, Dechev G, Mihnea R, Serbanescu O, Unluata U (1990) State of the marine environment in the Black Sea region. UNEP Reg Seas Rep Stud 124

Banse K, English DC (1994) Seasonality of coastal zone color scanner phytoplankton pigment in the offshore oceans. J Geophys Res 99(C4):7323-7345

Becacos-Kontos T (1977) Primary production and environmental factors in an oligotrophic biome in the Aegaen Sea. Mar Biol 42:93-98

Berseneva GP (1993) Chlorophyll 'a' concentration seasonal variability. In: Kovalev AV, Finenko ZZ (eds) Plankton of the Black Sea. Naukova Dumka, Kiev, p 92-109 (in Russian)

Bologa AS (1986) Planctonic primary productivity of the Black Sea. A review. Thalassia Jugosl 22:1-22

Bologa AS, Frangopol PT, Vedernikov VI, Stelmakh LV, Yunev OA, Yilmaz A, Oguz T (1999) Distribution of planktonic primary production in the Black Sea. In: Besiktepe ST, Unluata U, Bologa AS (eds) NATO TU-Black Sea Project: environmental degradation of the Black Sea: challenges and remedies. Kluwer Academic Publishers, Dordrecht, p 131-145

Caddy JF (1993) Towards a cooperative evaluation of human impacts on fishery ecosystems of enclosed and semienclosed seas. Fishery Sci 1:57-95

Chebotarev YuS, Moiseev YeV, Kopiliv AI, Sorokin YuI, Mamaeva T.I. (1983) Seasonal variation of nutrients and primary production in the littoral zone of the Black Sea near Gelendzhik Bay. In: Sorokin YuI, Vinogradov ME (eds) Seasonal changes of plankton on the Black Sea. Nauka, Moscow, p 84-91 (in Russian)

Chirea R, Gomoiu T (1986) Some preliminary data on the nutrient influx into western Black Sea. Cercet Mar 19: 171-189

Cociasu A, Dorogan L, Humborg C, Popa L (1996) Long-term ecological changes in Romanian coastal waters of the Black Sea. Mar Pollut Bull 32:32-38

Codispoti LA, Friederich GE, Murray JW, Sakamoto CM (1991) Chemical variability in the Black Sea: implications of continuous vertical profiles that penetrated the oxic/anoxic interface. Deep-Sea Res Part A Oceanogr Res Pap 38:691-710

Cokacar T, Ozsoy E (1998) Comparative analyses and modelling for regional ecosystems of the Black Sea. In: Ivanov L, Oguz T (eds) NATO TU-Black Sea Project: ecosystem modeling as a management tool for the Black Sea, Vol. 2. Kluwer Academic Publishers, Dordrecht, p 323-357

Curl H, Small LF (1965) Variations in photosynthetic assimilation ratios in natural marine phytoplankton communities. Limnol Oceanogr (Suppl) 10:R67-R73

Demidov AB (1999) Spatial and temporal variability of chlorophyll ' $a$ ' in the Black Sea in the winter-spring period. Oceanology 39:688-700 (English translation)

Eppley RW, Harrison WG, Chisholm SW, Stewart E (1977) Particulate organic matter in surface waters off Southern California and its relationship to phytoplankton. J Mar Res 35:671-696

Eremeev VN, Ivanov LM, Kochergin SV, Melnichenko OV (1992) Seasonal variability and types of currents in the upper layer of the Black Sea. Sov J Phys Oceanogr 3: 193-208

Finenko ZZ (1965) Primary production of the Black and Azov Seas as well as the tropical part of the Atlantic Ocean. PhD thesis, Byelorussian State University, Minsk (in Russian)

Finenko ZZ (1967) Primary production of the southern seas. In: Vodyanitsky VA (ed) The problems of biooceanography. Naukova Dumka, Kiev, p 69-74 (in Russian)

Finenko ZZ (1979) Phytoplankton production. In: Greze VN (ed) Principles of the biological productivity of the Black Sea. Naukova Dumka, Kiev, p 88-99 (in Russian)

Finenko ZZ, Krupatkina DK (1993) Primary production in the Black Sea during winter-spring period. Oceanology 33: 94-104 (English translation)

Georgieva LV (1993) Species composition and the dynamics of phytocen. In: Kovalev AV, Finenko ZZ (eds) Plankton of the Black Sea. Naukova Dumka, Kiev, p 33-55 (in Russian)

Gucu A (1997) Role of fishing in the Black Sea ecosystem. In: Ozsoy E, Mikaelyan A (eds) Sensitivity to change: Black Sea, Baltic Sea and North Sea. Kluwer Academic Publishers, Dordrecht, p 149-162

Humborg C, Ittekkot V, Cociasu A, von Bodungen B (1997) Effect of Danube River dam on Black Sea biogeochemistry and ecosystem structure. Nature (Lond) 386:385-388

Ivanov LI, and 27 others (1998) Physical, chemical and biological data sets of the TU Black Sea Data Base: description and evaluation. In: Ivanov L, Oguz T (eds) NATO TUBlack Sea Project: ecosystem modeling as a management tool for the Black Sea, Vol I. Kluwer Academic Publishers, Dordrecht, p 11-38

Jeffrey SW, Humphrey GF (1975) New spectrophotometric equations for determining chlorophylls $a, b, c_{1}$ and $c_{2}$ in higher plants, algae and natural phytoplankton. Biochem Physiol Pflanz (BPP) 167:191-194 
JGOFS (Joint Global Ocean Flux Study) Protocols (1994) Protocols for the Joint Global Ocean Flux Study (JGOFS). Core Meas, Manual Guides 29:97-100

Kideys AE (1994) Recent dramatic changes in the Black Sea ecosystem: the reason for the sharp decline in Turkish anchovy fisheries. J Mar Syst 5:171-181

Kideys AE, Gordina A, Bingel F, Niermann U (1999) The effect of environmental conditions on the distribution of eggs and larvae of anchovy (Engraulis encrasicolus) in the Black Sea. J Mar Syst 56:58-64

Kideys AE, Kovalev AV, Shulman G, Gordina A, Bingel F (2000) A review of zooplankton investigations of the Black Sea over the last decade. J Mar Syst 24:355-371

Klyashtorin LB, Rukhlov FN (1998) Long-term climate change and pink salmon stock fluctuation. North Pac Anadr Fish Comm Bull 1:464-479

Konovalov SK, Ivanov LI, Murray JW, Eremeeva LV (1999) Eutrophication: a plausible cause for changes in hydrochemical structure of the Black Sea anoxic layer. In: Besiktepe ST, Unluata U, Bologa AS (eds) NATO TU-Black Sea Project: environmental degradation of the Black Sea: challenges and remedies. Kluwer Academic Publishers, Dordrecht, p 61-74

Konovalov SK, Murray JW (2001) Variations in the chemistry of the Black Sea on a time scale of decades (1965-1995). J Mar Syst 31:217-243

Konsulov A, Kamburska L (1998) Black Sea zooplankton structural dynamics and variability off the Bulgarian Black Sea coast during 1991-1995. In: Ivanov L, Oguz T (eds) NATO TU-Black Sea Project: ecosystem modeling as a management tool for the Black Sea, Vol I. Kluwer Academic Publishers, Dordrecht, p 281-292

Kopelevich OV, Sheberstov SV, Yunev O, Basturk O (2002) Surface chlorophyll in the Black Sea over 1978-1986 derived from satellite and in situ data. J Mar Syst (in press)

Kovalev AV, Niermann U, Melnikov VV, Belokopitov V, Uysal Z, Kideys AE, Unsal M (1998) Long-term changes in the Black Sea zooplankton: the role of natural and anthropogenic factors. In: Ivanov L, Oguz T (eds) NATO TUBlack Sea Project: ecosystem modeling as a management tool for the Black Sea, Vol I. Kluwer Academic Publishers, Dordrecht, p 221-234

Krupatkina DK, Yunev OA, Zhorov SV (1990) Primary production, chlorophyll and size structure of the Black Sea phytoplankton in the winter and early spring. Ekol Morya 36:87-91 (in Russian)

Krupatkina DK, Finenko ZZ, Shalapyonok AA (1991) Primary production and size-fractionated structure of the Black Sea phytoplankton in the winter-spring period. Mar Ecol Prog Ser 73:25-31

Lakin GF (1990) Biometrics. Vischaya Schkola, Moscow (in Russian)

MacLennan DN, Yasuda T, Mee L (1997) Analyses of the Black Sea fishery fleet and landings. BSEP-PCU, Dolmabahce Sarayi, II Harekat Kosku, 80680 Besiktas, Istambul

Mankovsky VI, Vladimirov VL, Afonin EI, Mishonov AV, Solovev MV, Anninsky BE, Georgieva LV, Yunev OA (1996) Long-term variability of the Black Sea water transparency and reasons for its strong decrease in the late 1980s and early 1990s. Marine Hydrophysical Institute and the Institute of Biology of the Southern Seas, Sevastopol (in Russian)

Mann KH (1993) Physical oceanography, food chains, and fish stocks. ICES J Mar Sci 50:105-119

Mantoura RFC, Jeffrey SW, Llewellyn CA, Claustre $H$, Morales CE (1997) Comparison between spectrophotometric, fluorometric and HPLC methods for chlorophyll analysis. In: Jeffrey SW, Mantoura RFC, Wright SW (eds) Phytoplankton pigments in oceanography: guidelines to modern methods. UNESCO, Paris, p 361-380

Matsudaira Y (1964) Cooperative studies of primary productivity in the coastal waters of Japan 1962-63. Inf Bull Planktol Jpn 11:24-73

Mee L (1992) The Black Sea in crisis: call for concerned international action. Ambio 21:278-286

Menzel DW, Ryther JH (1960) The annual cycle of primary production in the Sargasso Sea off Bermuda. Deep-Sea Res 6:351-367

Mikaelyan AS (1996) Longtime variability in phytoplankton communities in the open waters of the Black Sea related to environmental changes. In: Ozsoy E, Mikaelyan A (eds) Sensitivity to change: Black Sea, Baltic Sea and North Sea. Kluwer Academic Publishers, Dordrecht, p 105-116

Mutlu E, Bingel F, Gucu AC, Melnikov VV, Niermann U, Ostrovskaya NA, Zaika VE (1994) Distribution of the new invader Mnemiopsis sp. and the resident Aurelia aurita and Pleurobrachia pileus populations in the Black Sea in the years 1991-1993. ICES J Mar Sci 51:407-421

Neveux J, Delmas D, Romano JC, Algarra P and 8 others (1990) Comparison of chlorophyll and phaeopigment determinations by spectrophotometric, fluorometric, spectrofluorometric and HPLC methods. Mar Microb Food Webs 4:217-238

Niermann U, Bingel F, Gorban A, Gordina AD and 6 others (1994) Distribution of anchovy eggs and larvae (Engraulis encrasicolus Cuv.) in the Black Sea in 1991 and 1992 in comparison to former surveys. ICES J Mar Sci 51:395-406

Niermann U, Kideys AE, Kovalev AV, Melnikov V, Belokopytov V (1999) Fluctuations of pelagic species of the open Black Sea during 1980-1995 and possible teleconnections. In: Besiktepe ST, Unluata U, Bologa AS (eds) NATO TUBlack Sea Project: environmental degradation of the Black Sea: challenges and remedies. Kluwer Academic Publishers, Dordrecht, p 147-173

Oguz T, Latun VS, Latif MA, Vladimirov VV, Sur HI, Markov AA, Ozsoy E, Kotovshchikov BB, Eremeev VN, Unluata U (1993) Circulation in the surface and intermediate layers of the Black Sea. Deep-Sea Res 40:1597-1612

Ovchinnikov IM, Popov YuI (1987) Formation of a cold intermediate layer in the Black Sea. Okeanologiya 27:739-746 (in Russian)

Ozsoy E, Unluata U (1997) Oceanography of the Black Sea. A review of some recent results. Earth-Sci Rev 42:231-272

Petipa TS (1981) The trophodynamics of copepods in the marine planktonic communities. Naukova Dumka, Kiev (in Russian)

Petranu A, Apas M, Bodeanu N, Bologa AS, Dumitrache C, Moldoveanu M, Radu G, Tiganus V (1999) Status and evolution of the Romanian Black Sea coastal ecosystem. In: Besiktepe ST, Unluata U, Bologa AS (eds) NATO TUBlack Sea Project: environmental degradation of the Black Sea: challenges and remedies. Kluwer Academic Publishers, Dordrecht, p 175-195

Raymont JEG (1980) Plankton and productivity in the oceans, 2nd edn, Vol 1, Phytoplankton. Pergamon Press, Oxford

Richardson K (1991) Comparison of ${ }^{14} \mathrm{C}$ primary production determinations made by different laboratories. Mar Ecol Prog Ser 72:189-201

Ryther JH, Yentsch CS (1958) Primary production of continental shelf waters off New York. Limnol Oceanogr 3: 327-335

Saydam C, Tugrul S, Basturk O, Oguz T (1993) Identification of the oxic/anoxic interface by isopycnal surfaces in the Black Sea. Deep-Sea Res 40:1405-1412 
SCOR-UNESCO (1966) Report of SCOR-UNESCO working group 17 on determination of photosynthetic pigments in sea water. Monogr Oceanogr Methodol 1:9-18

Shiganova TA (1998) Invasion of the Black Sea by the ctenophore Mnemiopsis leidyi and recent changes in pelagic community structure. Fish Oceanogr 7:305-310

Shiganova TA, Kideys AE, Gucu AC, Niermann U, Khoroshilov VS (1998) Changes of species diversity and abundance in the main components of the Black Sea pelagic community during last decade. In: Ivanov L, Oguz T (eds) NATO TU-Black Sea Project: ecosystem modeling as a management tool for the Black Sea, Vol I. Kluwer Academic Publishers, Dordrecht, p 171-188

Sorokin Yu I (1983) The Black Sea. In: Ketchum BH (ed) Estuaries and enclosed sea ecosystem of the world, Vol 26. Elsevier, Amsterdam, p 253-292

Steemann Nielsen E (1952) The use of radioactive carbon $\left(\mathrm{C}^{14}\right)$ for measuring organic production in the sea. J Cons Perm Int Explor Mer 18:117-140

Stelmakh LV, Yunev OA, Finenko ZZ, Vedernikov VI, Bologa AS, Churilova TYu (1998) Peculiarities of seasonal variability of primary production in the Black Sea. In: Ivanov L, Oguz T (eds) NATO TU-Black Sea Project: ecosystem modeling as a management tool for the Black Sea, Vol I. Kluwer Academic Publishers, Dordrecht, p 93-104

Sur H, Ozsoy E, Unluata U (1994) Boundary current instabilities, upwelling, shelf mixing and eutrophication processes in the Black Sea. Progr Oceanogr 33:249-302

Sur H, Ozsoy E, Ilyin YP, Unluata U (1996) Coastal/deep interactions in the Black Sea and their ecological/environmental impacts. J Mar Syst 7:293-320

Tolmazin D (1985) Changing coastal oceanography of the Black Sea. 1. Northwestern Shelf. Progr Oceanogr 15: 217-276

Tugrul S, Basturk O, Saydam C, Yilmaz A (1992) Changes in the hydrochemistry of the Black Sea inferred from water density profiles. Nature (Lond) 359:137-139

Unluata U, Aubrey DG, Belberov Z, Bologa A, Eremeev V, Vinogradov $M$ (1993) International program investigates the Black Sea. EOS Trans Am Geophys Un 74:401/407/412

USGOFSO (US Global Ocean Flux Study Office) (1989) Ocean color from space, Mediterranean image. A folder of CZCS images prepared by NSF/NASA-sponsored US Global Ocean Flux Study Office, Woods Hole Oceanographic Institution, Woods Hole, MA

Vedernikov VI (1989) Primary production and chlorophyll in the Black Sea in the summer-fall season. In: Vinogradov ME, Fliut MV (eds) The structure and production characteristics of plankton communities in the Black Sea. Nauka, Moscow, p 65-83 (in Russian)

Vedernikov VI (1991) The specifics of the distribution of primary production and chlorophyll in the Black Sea in the spring and summer. In: Vinogradov ME (ed) The variability of the Black Sea ecosystem: natural and anthropogenic factors. Nauka, Moscow, p 128-147 (in Russian)

Vedernikov VI, Demidov AB (1993) Primary production and chlorophyll in deep regions of the Black Sea. Oceanology 33:193-199 (English translation)

Vedernikov VI, Demidov AB (1997) Vertical distribution of primary production and chlorophyll during different seasons in deep regions of the Black Sea. Oceanology 37 : 376-384 (English translation)

Vedernikov VI, Konovalov BV, Koblents-Mishke OI (1980) Peculiarities of primary production and chlorophyll distribution in the Black Sea in autumn 1978. In: Vinogradov ME (ed) The Black Sea pelagial ecosystem. Nauka, Moscow, p 105-117 (in Russian)
Vedernikov VI, Konovalov BV, Koblents-Mishke OI (1983) Seasonal variations of phytoplankton pigments in the near-shore waters of the northeastern Black Sea. In: Sorokin YuI, Vedernikov VI (eds) Seasonal variations of the Black Sea plankton. Nauka, Moscow, p 66-84 (in Russian)

Vedernikov VI, Demidov AB, Korneeva GA (1996) Some features of distribution of phytoplankton production characteristics and rate of hydrolysis of natural polymers in the Black Sea in autumn. Oceanology 36:231-240 (English translation)

Vinogradov ME, Sapozhnikov VV, Shushkina EA (1992) The Black Sea ecosystem. Nauka, Moscow (in Russian)

Vinogradov ME, Shushkina EA, Mikaelyan AS, Nezlin NP (1999) Temporal (seasonal and interannual) changes of ecosystem of the open waters of the Black Sea. In: Besiktepe ST, Unluata U, Bologa AS (eds) NATO TU-Black Sea Project: environmental degradation of the Black Sea: challenges and remedies. Kluwer Academic Publishers, Dordrecht, p 109-129

Vladimirov VL, Mankovsky VI, Solovev MV, Mishonov AV (1997) Seasonal and long-term variability of the Black Sea optical parameters. In: Ozsoy E, Mikaelyan A (eds) Sensitivity to change: Black Sea, Baltic Sea and North Sea. Kluwer Academic Publishers, Dordrecht, p 33-48

Volovik SP, Dubinina VG, Semenov AD (1993) Fisheries and environment studies in the Black Sea system. Part 1. Hydrobiology and dynamics of fishing in the Azov. Stud Rev Gen Fish Counc Mediterr (FAO) 64:1-58

Williams RB, Murdoch MB (1966) Phytoplankton production and chlorophyll concentration in the Beaufort Channel, North Carolina. Limnol Oceanogr 11:73-82

Yayla MK, Yilmaz A, Morkoc E (2001) The dynamics of nutrient enrichment and primary production related to the recent changes in the ecosystem of the Black Sea. Aquat Ecosyst Health Manag 4:31-49

Yilmaz A, Tugrul S, Polat LC, Ediger D, Coban Y, Morkoc E (1998a) On the production, elemental composition (C, N, $\mathrm{P})$ and distribution of photosynthetic organic matter in the southern Black Sea. Hydrobiologia 363:141-156

Yilmaz A, Yunev O, Vedernikov V, Moncheva S, Bologa AS, Cociasu A, Ediger D (1998b) Unusual temporal variations in the spatial distribution of chlorophyll $a$ in the Black Sea during 1990-1996. In: Ivanov L, Oguz T (eds) NATO TUBlack Sea Project: ecosystem modeling as a management tool for the Black Sea, Vol I. Kluwer Academic Publishers, Dordrecht, p 105-120

Yunev OA (1989) Spatial distribution of chlorophyll 'a' and phaeophetin ' $a$ ' in the western Black Sea in winter. Oceanologia 29:480-485 (in Russian)

Yunev OA, Burlakova ZP, Krupatkina DK, Berseneva GP, Churilova TYa (1987) Seasonal variability of chlorophyll in the western Black Sea surface layer. In: Urdenko VA, Zimmerman G (eds) Optical remote sensing of the sea and the influence of the atmosphere: Program of 'Intercosmos', Vol 2, Part 2. Institute of Cosmic Investigation of GDR Academy of Science. Moscow, Berlin, Sevastopol, p 181-197 (in Russian)

Zaitsev YuP (1993) Impacts of eutrophication on the Black Sea fauna. Stud Rev Gen Fish Counc Mediterr (FAO) 64:63-86

Zaitsev YuP, Aleksandrov BG (1997) Recent man-made changes in the Black Sea ecosystem. In: Ozsoy E, Mikaelyan A (eds) Sensitivity to change: Black Sea, Baltic Sea and North Sea. Kluwer Academic Publishers, Dordrecht, p 25-32

Zar JH (1984) Biostatistical analysis, 2nd edn. Prentice-Hall Inc, Englewood Cliffs, NJ 